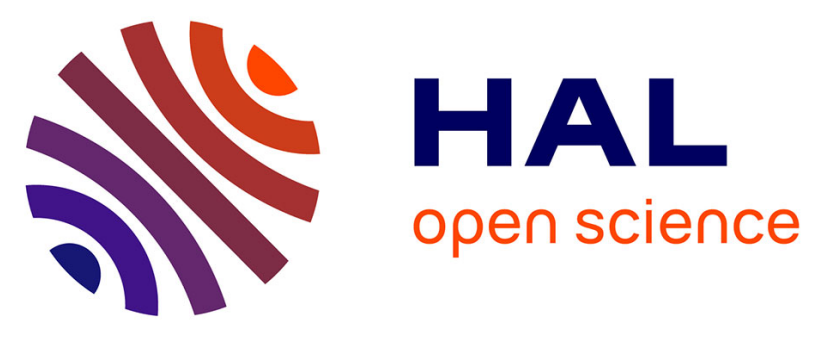

\title{
Crystal structure of the enoyl-ACP reductase of Mycobacterium tuberculosis (InhA) in the apo-form and in complex with the active metabolite of isoniazid pre-formed by a biomimetic approach
}

Aurélien Chollet, Lionel Mourey, Christian Lherbet, Alexandra Delbot, Sylviane Julien, Michel Baltas, Jean Bernadou, Geneviève Pratviel, Laurent Maveyraud, Vania Bernardes-Génisson

\section{- To cite this version:}

Aurélien Chollet, Lionel Mourey, Christian Lherbet, Alexandra Delbot, Sylviane Julien, et al.. Crystal structure of the enoyl-ACP reductase of Mycobacterium tuberculosis (InhA) in the apo-form and in complex with the active metabolite of isoniazid pre-formed by a biomimetic approach. Journal of Structural Biology, 2015, 190, pp.328 - 337. 10.1016/j.jsb.2015.04.008 . hal-03002973

\section{HAL Id: hal-03002973 \\ https://hal.science/hal-03002973}

Submitted on 20 Nov 2020

HAL is a multi-disciplinary open access archive for the deposit and dissemination of scientific research documents, whether they are published or not. The documents may come from teaching and research institutions in France or abroad, or from public or private research centers.
L'archive ouverte pluridisciplinaire HAL, est destinée au dépôt et à la diffusion de documents scientifiques de niveau recherche, publiés ou non, émanant des établissements d'enseignement et de recherche français ou étrangers, des laboratoires publics ou privés. 


\title{
Crystal structure of the enoyl-ACP reductase of Mycobacterium tuberculosis (InhA) in the apo-form and in complex with the active metabolite of isoniazid pre-formed by a biomimetic approach
}

\author{
Aurélien Chollet ${ }^{\mathrm{a}, \mathrm{b}}$, Lionel Mourey ${ }^{\mathrm{c}, \mathrm{d}}$, Christian Lherbet $^{\mathrm{e}, \mathrm{f}}$, Alexandra Delbot ${ }^{\mathrm{e}, \mathrm{f}}$, Sylviane Julien ${ }^{\mathrm{c}, \mathrm{d}}$, \\ Michel Baltas ${ }^{\mathrm{e}, \mathrm{f}}$, Jean Bernadou ${ }^{\mathrm{a}, \mathrm{b}}$, Geneviève Pratviel ${ }^{\mathrm{a}, \mathrm{b}}$, Laurent Maveyraud ${ }^{\mathrm{c}, \mathrm{d}, *}$, \\ Vania Bernardes-Génisson ${ }^{\mathrm{a}, \mathrm{b}, *}$ \\ ${ }^{a}$ Laboratoire de Chimie de Coordination (LCC), Centre National de la Recherche Scientifique (CNRS), 205 Route de Narbonne, BP 44099, F-31077 Toulouse, Cedex 4, France \\ ${ }^{\mathrm{b}}$ Université de Toulouse, Université Paul Sabatier, INPT, F-31077 Toulouse, Cedex 4, France \\ ${ }^{\mathrm{C}}$ Institut de Pharmacologie et de Biologie Structurale (IPBS), Centre National de la Recherche Scientifique (CNRS), 205 Route de Narbonne, BP 64182, F-31077 Toulouse, France \\ ${ }^{\mathrm{d}}$ Université de Toulouse, Université Paul Sabatier, IPBS, Toulouse F-31077, France \\ ${ }^{\mathrm{e}}$ Laboratoire de Synthèse et Physicochimie de Molécules d'Intérêt Biologique (SPCMIB), Centre National de la Recherche Scientifique (CNRS), 118 Route de Narbonne, 31062 \\ Toulouse, Cedex 9, France \\ ${ }^{\mathrm{f}}$ Université de Toulouse, Université Paul Sabatier, LSPCMIB, F-31077 Toulouse, France
}

\section{A R T I C L E I N F O}

\section{Article history:}

Received 21 October 2014

Received in revised form 9 April 2015

Accepted 10 April 2015

Available online 17 April 2015

\section{Keywords:}

Mycobacterium tuberculosis

Enoyl-ACP reductase

Apo InhA

Isoniazid

INH-NADH adduct

$\mathrm{X}$-ray structure

Differential scanning fluorimetry

\begin{abstract}
A B S T R A C T
InhA is an enoyl-ACP reductase of Mycobacterium tuberculosis implicated in the biosynthesis of mycolic acids, essential constituents of the mycobacterial cell wall. To date, this enzyme is considered as a promising target for the discovery of novel antitubercular drugs. In this work, we describe the first crystal structure of the apo form of the wild-type InhA at $1.80 \AA \AA$ resolution as well as the crystal structure of InhA in complex with the synthetic metabolite of the antitubercular drug isoniazid refined to $1.40 \AA$. This metabolite, synthesized in the absence of InhA, is able to displace and replace the cofactor NADH in the enzyme active site. This work provides a unique opportunity to enlighten the structural adaptation of apo-InhA to the binding of the NADH cofactor or of the isoniazid adduct. In addition, a differential scanning fluorimetry study of InhA, in the apo-form as well as in the presence of $\mathrm{NAD}^{+}, \mathrm{NADH}$ and INH-NADH was performed showing that binding of the INH-NADH adduct had a strong stabilizing effect.
\end{abstract}

(c) 2015 Elsevier Inc. All rights reserved.

\section{Introduction}

Tuberculosis, an old chronic pathology caused by the bacillus Mycobacterium tuberculosis (Mtb), continues to threaten mankind as it is one of the major causes of death worldwide resulting from a single pathogen. According to World Health Organization (WHO), 8.6 million new cases of tuberculosis arose in 2012, and 1.3 million people died from this disease (World Health Organization, 2013a). Current tuberculosis therapeutic strategy requires a two-month

\footnotetext{
* Corresponding authors at: Institut de Pharmacologie et de Biologie Structurale (IPBS), Centre National de la Recherche Scientifique (CNRS), 205 Route de Narbonne, BP 64182, F-31077 Toulouse, France (L. Maveyraud). Laboratoire de Chimie de Coordination (LCC), Centre National de la Recherche Scientifique (CNRS), 205 Route de Narbonne, BP 44099, F-31077 Toulouse, Cedex 4, France (V. BernardesGénisson).

E-mail addresses: laurent.maveyraud@ipbs.fr (L. Maveyraud), vania.bernardes-genisson@lcc-toulouse.fr (V. Bernardes-Génisson).
}

administration of four frontline drugs (isoniazid, rifampicin, ethambutol and pyrazinamide) followed by a four-month treatment with isoniazid and rifampicin (World Health Organization, 2010). This treatment is however challenged in case of infection by multidrug resistant (MDR), extremely drug resistant (XRD) or totally drug resistant (TDR) Mtb strains (World Health Organization, 2013b; Velayati et al., 2009). MDR-Mtb strains are resistant to at least isoniazid and rifampicin, and they require the resort to more expensive second line drugs such as streptomycin, moxifloxacin, and cycloserine, which present a higher level of adverse effects. XDR-Mtb strains are MDR-Mtb strains that are also resistant to quinolones and to some of the second-line drugs, whereas TDR-Mtb strains are resistant to all tested molecules (World Health Organization, 2013b; Velayati et al., 2009; Cegielski, 2010). The increasing occurrence of these resistant Mtb strains, as well as co-infection with human immunodeficiency virus (HIV), is highly preoccupant. Indeed, the incidence of 
incurable cases due to resistant strains is increasing (Cegielski, 2010). This context underlines the need for new drugs able to overcome the resistance mechanisms of Mtb. The finding of such drugs requires the elucidation of the molecular mechanisms of action of the current anti-tubercular drugs as well as the identification of new promising targets.

The front-line drug isoniazid (INH, Fig. 1) is one of the most efficient medicines to treat tuberculosis, but it is increasingly challenged by resistant Mtb strains. Although INH has been used as an antitubercular agent since 1952, its molecular mechanism of action has only been partially elucidated (Bernardes-Génisson et al., 2013).

It is widely accepted that INH interferes with the biosynthesis of mycolic acids, essential long $\alpha$-alkylated and $\beta$-hydroxylated fatty acids found in the mycobacterial cell wall (Winder and Collins, 1970; Takayama et al., 1972, 1975; Davidson and Takayama, 1979). It inhibits the enoyl-ACP reductase (InhA), a NADH-dependent enzyme of the type II Fatty Acid Synthase system (FAS-II) that catalyzes the last reductive step of fatty acid elongation (Fig. 2). InhA is a member of the short chain dehydrogenase/ reductase superfamily of enzymes (Jörnvall et al., 1995). Its attractiveness as a target for the discovery of new antibiotics has been validated some years ago (Moir, 2005; Zhang et al., 2006; Lu et al., 2010). On the one hand, it is the main target of the confirmed drugs INH and ethionamide (ETH) (Banerjee et al., 1994) and on the other hand, InhA, as all enzymes of the FAS-II system, does not have a human ortholog. This reduces the risk of inhibitors of InhA being toxic to the human host (Moir, 2005). At the molecular level, INH behaves as a pro-drug requiring an oxidative activation by the Mtb catalase-peroxidase KatG to likely generate the isonicotinoyl radical. This radical species covalently reacts with the cellular nicotinamide adenine dinucleotide resulting in an isonicotinoyl-NADH adduct (INH-NADH), which is the actual inhibitor of the InhA target (Rozwarski et al., 1999) (Fig. 1).

Concerning the molecular mechanism of action of INH, it is not yet clear whether the reaction between the isonicotinoyl radical and NADH occurs within KatG, within InhA or in solution. Moreover the chemical form of the nucleotide pyridine moiety ( $\mathrm{NADH}, \mathrm{NAD}^{+}$or NAD') that reacts with the activated form of INH remains to be elucidated.

Based on an experiment containing all the reaction components necessary to form INH-NADH adduct (INH, $\mathrm{MnCl}_{2}, \mathrm{O}_{2}, \mathrm{NADH}$ ) except InhA, and in which no detectable amounts of INH-NADH adduct was produced, Rozwarski et al. (1998) proposed that INH$\mathrm{NADH}$ formation might occur exclusively within the active site of InhA (neither in solution nor within KatG) by recombination of the isonicotinoyl radical with the NAD radical generated from NADH as cofactor. Indeed, the same reaction, carried out in the presence of InhA, resulted in the formation of the expected adducts. In contrast, Wilming and Johnsson (1999) suggested, as a more probable mechanism, a direct addition of the isonicotinoyl radical to the oxidized form of the cofactor $\left(\mathrm{NAD}^{+}\right)$and subsequent

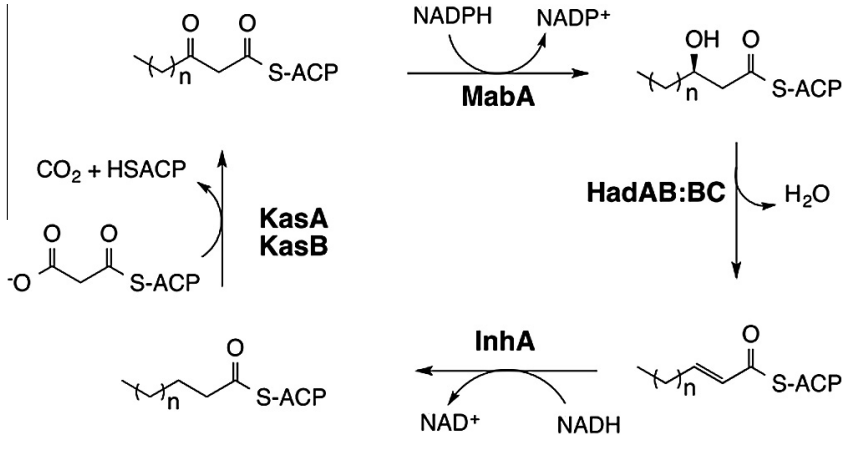

Fig.2. Schematic representation of the Fatty Acid Synthase II.

reduction of the formed cation radical. Indeed, according to these authors, the addition of the acyl radical upon $\mathrm{NAD}^{+}$occurs very quickly. Given the low intra-cellular concentration of $\mathrm{NAD}^{+}$(micromolar range) and the low binding affinity of InhA for $\mathrm{NAD}^{+}$ (Quémard et al., 1995), the resulting amount of $\mathrm{NAD}^{+}$-InhA complex would be too low to account for the formation of the INH$\mathrm{NADH}$ adduct.

Another point that also needs to be addressed is the nature of the active tautomeric form of INH-NADH (open keto amide or cyclic hemiamidal) (Fig. 3). Taking into account that the two forms of tautomers (open keto-amide adduct $\mathbf{1}$ and cyclic hemiamidal adducts 2) (Fig. 3) are observed in solution, one may question if it is uniquely the open keto-amide form of the INH-NADH adduct that binds in the active site of InhA or if the cyclic hemiamidal adducts, once formed, would also be able to interact with InhA (Nguyen et al., 2001a, 2001b, 2002).

Several crystal structures of wild-type InhA are described in the literature and deposited in the Protein Data Bank (PDB): in complex with NADH (Dessen et al., 1995; Oliveira et al., 2006; Molle et al., 2010; Hartkoorn et al., 2012), with an analogue of the $C_{16}$ substrate (Rozwarski et al., 1999) or with various inhibitors (Dias et al., 2007; Argyrou et al., 2007; Kuo et al., 2003; Sullivan et al., 2006; Wang et al., 2007; Hartkoorn et al., 2014) including the INH-NADH adduct generated by oxidation of INH using $\mathrm{MnCl}_{2}$ in the presence of the InhA enzyme and NADH. However, despite this wealth of structural data, the structure of the apo-form of wildtype InhA has never been reported. Herein, we report the first crystal structure of the apo-form of wild-type InhA at $1.80 \AA$ resolution. Additionally, using differential scanning fluorimetry (DSF), we show that the INH-NADH adduct, preformed by a biomimetic approach (Nguyen et al., 2001a, 2001b), induced a significant increase of the melting temperature $\left(T_{\mathrm{m}}\right)$ of InhA, suggesting the occurrence of a strong interaction. Finally, the $1.40 \AA$ resolution structure of InhA in complex with this adduct was obtained and a comparison of this structure with those of the InhA in the apoform and bound to NADH is disclosed.

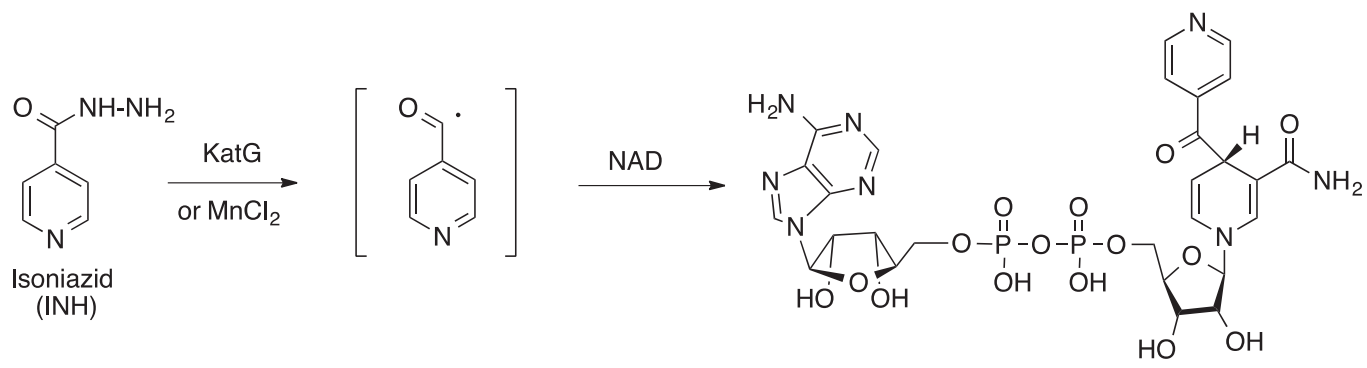

Fig.1. Chemical structure of isoniazid and mechanism of formation of the INH-NADH adduct. 


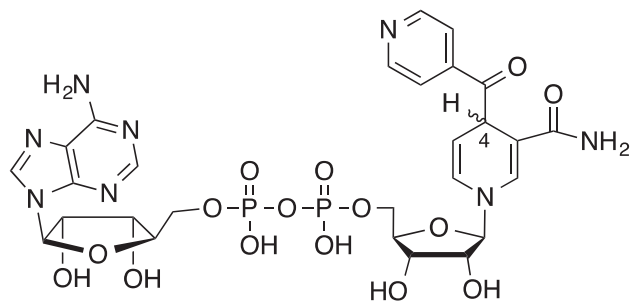

1 (open keto-amide adducts)

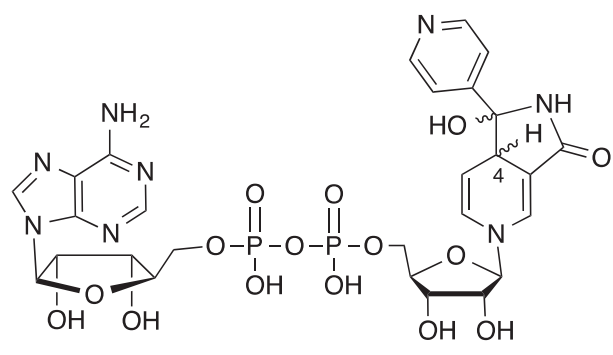

2 (cyclic hemiamidal adducts)

Fig.3. The covalent INH-NADH adducts: open keto-amide (1) and cyclic hemiamidals (2) adducts.

\section{Materials and methods}

\subsection{Preparation of INH-NADH adduct}

Preparation and purification of the pool of INH-NADH adducts was carried out as previously described (Nguyen et al., 2001a; Broussy et al., 2003). Briefly, the reaction medium (15 mL final volume) contained INH (2 mM), $\mathrm{NAD}^{+}(2 \mathrm{mM})$ and $\mathrm{Mn}^{\mathrm{III}}$ pyrophosphate ( $4 \mathrm{mM}$, prepared as described in Nguyen et al., 2001a) in phosphate buffer $(100 \mathrm{mM}, \mathrm{pH} 7.5)$ and was stirred at RT for 20 min. The pool of adducts (Fig. 3) was separated from other components of the reaction mixture by using a Sep Pak ${ }^{\circledR}$ Vac C18 $20 \mathrm{cc}$ $(5 \mathrm{~g})$ cartridge. The reaction mixture was loaded in the cartridge and washed with $4 \mathrm{mM} \mathrm{NH} \mathrm{m}_{4} \mathrm{OAc}$ aqueous solution; only the pool of adducts was retained. Washing with water followed by elution with acetonitrile and concentration to dryness under vacuum afforded the pool of adducts. The resulting compounds were characterized using UV-visible (Fig. S1) and by ${ }^{1} \mathrm{H}$ NMR spectroscopy (Fig. S2).

\subsection{Expression and purification of InhA}

The pET15b (Novagen) plasmid with the inhA gene ligated into Nde1 and BamH1 restriction sites was generously provided by J.S. Blanchard (Albert Einstein College of Medicine of Yeshiva University). Escherichia coli BL21(DE3) cells were transformed with this plasmid and grown overnight at $37^{\circ} \mathrm{C}$ in LB medium containing $100 \mathrm{mg} / \mathrm{mL}$ of ampicillin. This pre-culture was diluted 30 -fold in fresh LB medium with ampicillin $(100 \mathrm{mg} / \mathrm{mL})$, and grown at $37^{\circ} \mathrm{C}$ under agitation until the OD at $595 \mathrm{~nm}$ reached a value of $0.6-0.8$. Protein expression was induced with $1 \mathrm{mM}$ isopropyl- $\beta-$ D-1-thiogalactopyranoside (IPTG), and the culture was pursued for $4 \mathrm{~h}$ at $37^{\circ} \mathrm{C}$. Cells were harvested by centrifugation at $6000 \mathrm{~g}$ for $30 \mathrm{~min}$ at $4{ }^{\circ} \mathrm{C}$. The dry pellet was frozen at $-80^{\circ} \mathrm{C}$. Thawed cells ( $1.5 \mathrm{~g}$ ) were sonicated in $20 \mathrm{~mL}$ lysis buffer $(300 \mathrm{mM} \mathrm{NaCl}$, $10 \mathrm{mM}$ imidazole, $50 \mathrm{mM}$ sodium phosphate buffer, $\mathrm{pH} 8.0$ ). After centrifugation at $10,000 \mathrm{~g}$ for $45 \mathrm{~min}$ at $4{ }^{\circ} \mathrm{C}$, the supernatant was applied onto a nickel-chelated His-Trap HP $1 \mathrm{~mL}$ column (GE Healthcare) equilibrated with the binding buffer $(50 \mathrm{mM} \mathrm{NaCl}$, $10 \mathrm{mM}$ imidazole, $50 \mathrm{mM}$ sodium phosphate buffer, $\mathrm{pH} 8.0$ ). After washing the column, the $\mathrm{His}_{6}$-tagged InhA protein was eluted with an imidazole gradient solution from 25 to $300 \mathrm{mM}$ over a range of 20 column volumes. Fractions containing the target protein were pooled and applied on a PD-10 desalting columns (GE Healthcare) equilibrated with $150 \mathrm{mM} \mathrm{NaCl}, 30 \mathrm{mM}$ piperazine$N, N^{\prime}$-bis(2-ethanesulfonic acid) (PIPES), $\mathrm{pH} 6.8$ to remove imidazole. The $\mathrm{His}_{6}$-tag was cleaved off by thrombin digestion (1.3 units per mg of protein, Amersham Biosciences) overnight at room temperature under static conditions. The solution was filtered with a
$0.2 \mu \mathrm{m}$ filter and reloaded onto the nickel affinity column to separate uncut $\mathrm{His}_{6}$-tagged protein from the digested protein. The flowthrough was collected and loaded onto a HiLoad 16/60 Superdex 200 column (GE Healthcare) equilibrated with $150 \mathrm{mM} \mathrm{NaCl}$, $30 \mathrm{mM}$ PIPES, pH 6.8. The fractions containing the enzyme were collected and concentrated with a Vivaspin (cut-off $10 \mathrm{kDa}$ ) to a protein concentration of $10 \mathrm{mg} / \mathrm{mL}$.

\subsection{Thermostability studies of InhA}

The melting point $\left(T_{\mathrm{m}}\right)$ of InhA was determined by DSF in 96 well reaction plates. The final volume $(20 \mu \mathrm{L})$ comprised a mixture of enzyme $(5 \mu \mathrm{M})$ and Sypro-orange $(10 \times)$ (Invitrogen) in an aqueous buffer (30 mM PIPES, pH 6.8, $150 \mathrm{mM} \mathrm{NaCl}$ ). The thermal transition was monitored using a Real-Time PCR CFX96 System (BioRad) using a temperature gradient from 25 to $97^{\circ} \mathrm{C}$ with a $0.3^{\circ} \mathrm{C}$ increment. $T_{\mathrm{m}}$ was given by the inflection point of the curve of the relative fluorescence unit $(\mathrm{RFU})=f(T)$ which matches to the lower value of the first derivative of RFU $(-d(\mathrm{RFU}) / d T)$ versus temperature. Studies were performed on the InhA apo-protein and in the presence of $2.5 \mathrm{mM} \mathrm{NADH}$ or $\mathrm{NAD}^{+}$. Control experiments were carried out in the presence of $5 \%$ DMSO $(\mathrm{v} / \mathrm{v})$. INH-NADH adduct at $0.5 \mathrm{mM}$ was tested for binding to the apo InhA protein and for competition with $2.5 \mathrm{mM}$ of either NADH or $\mathrm{NAD}^{+}$. Results are given as average values \pm standard deviations of $T_{\mathrm{m}}$ for at least 4 experiments. The effect of several concentrations of INH-NADH adduct (from 0.005 to $2.5 \mathrm{mM}$ ) was evaluated with an enzyme concentration of $5 \mu \mathrm{M}$.

\subsection{Crystallization of InhA}

\subsubsection{Apo $\operatorname{Inh} A$}

Crystallization assays were performed using the sitting drop vapor diffusion method and crystallization kits from Hampton Research. $400 \mathrm{~nL}$ drops were formed by mixing $200 \mathrm{~nL}$ of protein solution with $200 \mathrm{~nL}$ of reservoir solution with a Nanodrop ExtY robot (Innovadyne) at $12{ }^{\circ} \mathrm{C}$. Crystals of InhA protein grew in reservoir solution containing $100 \mathrm{mM}$ sodium acetate, $100 \mathrm{mM} 2-(\mathrm{N}$ morpholino)ethanesulfonic acid (MES) pH 6.5 and 30\% (w/v) polyethyleneglycol (PEG) 400 from the PEG II crystallization kit (Qiagen).

\subsubsection{Co-crystallization of the InhA-NADH binary complex}

For the preparation of crystals of the binary complex, $1 \mathrm{~mL}$ of InhA at $1 \mathrm{mg} / \mathrm{mL}(34 \mu \mathrm{M})$ in $150 \mathrm{mM} \mathrm{NaCl}, 30 \mathrm{mM}$ PIPES, pH 6.8 was incubated $2 \mathrm{~h}$ on ice with a 100 fold molar excess of NADH. The resulting solution was concentrated to a protein concentration of $10 \mathrm{mg} / \mathrm{mL}$ and was directly used in the hanging drop vapor diffusion method. Three microliter drops were formed at $20^{\circ} \mathrm{C}$ by 
Table 1

X-ray diffraction data collection and refinement statistics.

\begin{tabular}{|c|c|c|c|}
\hline & InhA - apo & InhA - NADH & InhA - INH-NADH \\
\hline Beamline & SOLEIL, PX1 & SOLEIL, PX1 & SOLEIL, PX1 \\
\hline Wavelength $(\AA)$ & 0.98011 & 0.8856 & 0.98011 \\
\hline Spacegroup & $\mathrm{C} 2$ & $P 6_{2} 22$ & $P 6_{2} 22$ \\
\hline Cell parameters $\left(\AA,^{\circ}\right)$ & $\begin{array}{l}a=100.10, b=81.79 \\
c=187.24, \beta=95.62\end{array}$ & $a=b=98.12, c=139.16$ & $a=b=97.43, c=139.75$ \\
\hline Resolution range $(\AA)$ & $\begin{array}{l}46.98-1.80 \\
(1.91-1.80)\end{array}$ & $\begin{array}{l}49.06-1.95 \\
(2.07-1.95)\end{array}$ & $\begin{array}{l}48.72-1.40 \\
(1.48-1.40)\end{array}$ \\
\hline $\mathrm{Nb}$. of observations & $471,430(47,415)$ & $316,352(47,351)$ & $826,688(126,489)$ \\
\hline $\mathrm{Nb}$. of unique reflections & $136,555(19,942)$ & $29,499(4598)$ & $77,041(12,200)$ \\
\hline Multiplicity & $3.5(2.4)$ & $10.7(10.3)$ & $10.7(10.4)$ \\
\hline Completeness (\%) & $98.0(89.0)$ & $99.7(98.3)$ & $99.6(99.2)$ \\
\hline Rsym & $5.8(50.9)$ & $5.0(83.7)$ & $5.5(71.6)$ \\
\hline Rmeas & $6.7(63.9)$ & $5.2(88.1)$ & $8.8(75.3)$ \\
\hline$I / \sigma(I)$ & $12.6(1.5)$ & $29.2(4.0)$ & $21.1(2.9)$ \\
\hline CC $(1 / 2)$ & $99.8(67.5)$ & $100.0(97.7)$ & $99.9(97.7)$ \\
\hline Resolution range & $35.00-1.80$ & 49.06-1.95 & $40.00-1.40$ \\
\hline No. of reflections & 136,543 & 29,470 & 77,036 \\
\hline Rfactor & 0.1889 & 0.1808 & 0.1229 \\
\hline Rfree & 0.2191 & 0.2001 & 0.1513 \\
\hline \multicolumn{3}{|l|}{ No. of atoms } & 1 \\
\hline Protein & 11,299 & 2010 & 2082 \\
\hline Ligand & & 44 & 96 \\
\hline Solvent & 806 & 147 & 311 \\
\hline \multicolumn{4}{|l|}{ Rms deviations } \\
\hline Bond lengths ( $\AA / Z$-score) & $0.018 / 0.95$ & $0.009 / 0.45$ & $0.021 / 1.05$ \\
\hline Bond angles ( ${ }^{\circ} / Z$-score) & $1.747 / 0.89$ & $1.030 / 0.62$ & $2.174 / 0.95$ \\
\hline \multicolumn{4}{|l|}{ Ramachandran analysis } \\
\hline$\%$ favored/nb of residues & $96 / 1472$ & $96 / 258$ & $97 / 268$ \\
\hline$\%$ allowed/nb of residues & $3 / 48$ & $4 / 10$ & $3 / 8$ \\
\hline$\%$ outliers/nb of residues & $1 / 6$ & $0 / 0$ & $0 / 0$ \\
\hline \multicolumn{4}{|l|}{ Average $B$ factors $\left(\AA^{2}\right)$} \\
\hline Protein atoms & 41.6 & 54.3 & 30.6 \\
\hline Ligand atoms & & 44.3 & 20.8 \\
\hline Solvent atoms & 43.8 & 57.6 & 49.7 \\
\hline PDB ID & 4TRM & 4TRN & 4TRO \\
\hline
\end{tabular}

mixing $1 \mu \mathrm{L}$ of protein solution with $1 \mu \mathrm{L}$ of reservoir solution (100 mM 4-(2-hydroxyethyl)-1-piperazineethanesulfonic acid (HEPES) pH 7.5, 8-10\% 2-methyl-2,4-pentanediol (MPD), $50 \mathrm{mM}$ sodium citrate $\mathrm{pH} 6.5$ ) and $1 \mu \mathrm{L}$ of water.

\subsubsection{INH-NADH soaking experiments}

Crystals of the InhA-NADH binary complex were used for soaking experiments with the pool of open keto-amide and cyclized hemiamidal INH-NADH adducts. Crystals were soaked for $1 \mathrm{~h}$ into a $1 \mu \mathrm{L}$ drop of reservoir solution where $0.2 \mu \mathrm{L}$ of stock solution of INH-NADH (50 mM in DMSO) was added.

\subsection{Data collection and structure determination}

Crystals were cooled at $100 \mathrm{~K}$ by direct transfer in a gaseous nitrogen flux prior to data collection. Diffracted intensities were collected at the Proxima 1 beamline at the SOLEIL synchrotron facility (Saint-Aubin, France) (Table 1). Data were processed and scaled with AutoProc (Vonrhein et al., 2011) and XDS (Kabsch, 2010). Rigid-body refinement was used to account for variation of cell parameters compared to structures available in the PDB. The structure of InhA in the presence of $\mathrm{NAD}^{+}$and triclosan (PDB ID 2B35, (Sullivan et al., 2006)) was used as a starting model for the structure of apo-InhA, whereas the structure of InhA in the presence of NADH (PDB ID 1ENY, (Dessen et al., 1995)) was used for structures of InhA in the presence of NADH and with both $\mathrm{NADH}$ and INH-NADH. In each case, only protein atoms were kept in the starting model. Structure refinement was performed with Buster-TNT (Bricogne et al., 2011) and Coot (Emsley and Cowtan, 2004). Anisotropic B-factors were refined using Refmac (Murshudov et al., 2011) from the CCP4 suite of programs (Winn et al., 2011) (Table 1).

\section{Results and discussion}

\subsection{Synthesis of the pool of INH-NADH adducts}

The preparation of the pool of INH-NADH adducts was performed by a biomimetic activation of isoniazid by action of the manganese pyrophosphate and in the presence of the $\mathrm{NAD}^{+}$and in the absence of the protein InhA. After a purification step, UVvisible (Fig. S1) and ${ }^{1} \mathrm{H}$ NMR analysis (Fig. S2) showed spectroscopic data in accord with those described previously (Lei et al., 2000; Broussy et al., 2003) confirming that the pool of adducts was formed before the soaking experiments.

\subsection{Production and purification of InhA}

The overexpression of the recombinant $\mathrm{His}_{6}$-tagged InhA protein was carried out in a protease-deficient strain of $E$. coli (BL21) transformed with the pET15b/inhA plasmid at $37^{\circ} \mathrm{C}$ in $\mathrm{LB}$-medium. The purification procedure resulted in approximately $4.0 \mathrm{mg}$ of pure enzyme per liter of bacterial culture. 
Table 2

Thermal stability measurement.

\begin{tabular}{lllllll}
\hline $\begin{array}{l}\text { InhA } \\
\text { form }\end{array}$ & $T_{\mathrm{m}}\left({ }^{\circ} \mathrm{C}\right)$ & $\begin{array}{l}T_{\mathrm{m}}\left({ }^{\circ} \mathrm{C}\right) \\
(5 \%\end{array}$ & $\begin{array}{l}\Delta T_{\mathrm{m}} \\
\left({ }^{\circ} \mathrm{C}\right)^{\mathrm{a}}\end{array}$ & $\begin{array}{l}\Delta T_{\mathrm{m}} \\
\left({ }^{\circ} \mathrm{C}\right)^{\mathrm{b}}\end{array}$ & $\begin{array}{l}T_{\mathrm{m}}\left({ }^{\circ} \mathrm{C}\right)(5 \% \text { DMSO, } \\
500 \mu \mathrm{M} \text { adduct })\end{array}$ & $\begin{array}{l}\Delta T_{\mathrm{m}} \\
\left({ }^{\circ} \mathrm{C}\right)^{\mathrm{c}}\end{array}$ \\
\hline Apo & $57.6 \pm 0.8$ & $52.8 \pm 0.5$ & -4.8 & $\mathrm{n} / \mathrm{a}$ & $63.2 \pm 0.6$ & +10.4 \\
$\mathrm{NADH}$ & $59.8 \pm 0.4$ & $58.2 \pm 0.4$ & -1.6 & +5.4 & $63.6 \pm 0.0$ & +5.4 \\
$\mathrm{NAD}^{+}$ & $59.5 \pm 0.2$ & $53.8 \pm 0.3$ & -5.7 & +1.0 & $64.5 \pm 0.2$ & +10.7 \\
\hline
\end{tabular}

n/a: not applicable.

a $\Delta T_{\mathrm{m}}$ was calculated as $T_{\mathrm{m}}(\mathrm{Inh} \mathrm{A})$ in the presence of $5 \%$ DMSO minus $T_{\mathrm{m}}$ (InhA) in the absence of DMSO.

b $\Delta T_{\mathrm{m}}$ was calculated as $T_{\mathrm{m}}(\mathrm{InhA})$ in the presence of $\mathrm{NAD}(\mathrm{H})$ and DMSO minus $T_{\mathrm{m}}$ (InhA) with DMSO only.

c $\Delta T_{\mathrm{m}}$ was calculated comparing $T_{\mathrm{m}}$ (InhA) in the presence of INH-NADH with corresponding $T_{\mathrm{m}}$ with DMSO only.

3.3. Thermostability studies of apo-InhA, InhA in complex with $N A D^{+}$, $\mathrm{NADH}$ or INH-NADH

The InhA protein was engaged in DSF assays. The melting temperature $\left(T_{\mathrm{m}}\right)$ of the apo protein was evaluated at $57.6^{\circ} \mathrm{C}$ (Table 2 ). An increase in thermal stability of InhA was observed following the addition of NAD cofactor under its oxidized $\left(\mathrm{NAD}^{+}\right)$or reduced (NADH) form (respectively +1.9 and $+2.2{ }^{\circ} \mathrm{C}$, Table 2 and Fig. S3). In the presence of $5 \%$ DMSO $(\mathrm{v} / \mathrm{v})$, the $T_{\mathrm{m}}$ dropped to $52.8^{\circ} \mathrm{C}$ for the apo protein and to $53.8^{\circ} \mathrm{C}$ for InhA in the presence of $\mathrm{NAD}^{+}$; this corresponds to a decrease of 4.8 and $5.7^{\circ} \mathrm{C}$ respectively (Table 2 and Fig. S3). The thermal stability of the protein in the presence of NADH was less affected by the addition of DMSO, with a decrease of $T_{\mathrm{m}}$ of only $1.6^{\circ} \mathrm{C}$. Hence, the destabilizing effect of DMSO is largely attenuated in the presence of NADH but not of $\mathrm{NAD}^{+}$. These results are in agreement with the tight binding of $\mathrm{NADH}$ for InhA since $K_{\mathrm{m}}(\mathrm{NADH})$ is approximately 1000 -fold lower than $K_{\mathrm{m}}\left(\mathrm{NAD}^{+}\right.$) (Quémard et al., 1995).

The isoniazid active form prepared chemically has also been evaluated and data revealed a significant enhancement of the stability of the protein in all samples, with a $T_{\mathrm{m}}$ close to $64^{\circ} \mathrm{C}$ (Table 2 and Fig. S3). This correlates with the high affinity reported for the adduct, with a $K_{i}$ of $0.75 \mathrm{nM}$ (Rawat et al., 2003); INH-NADH seems therefore able to replace $\mathrm{NADH}$ or $\mathrm{NAD}^{+}$in the active site of InhA.

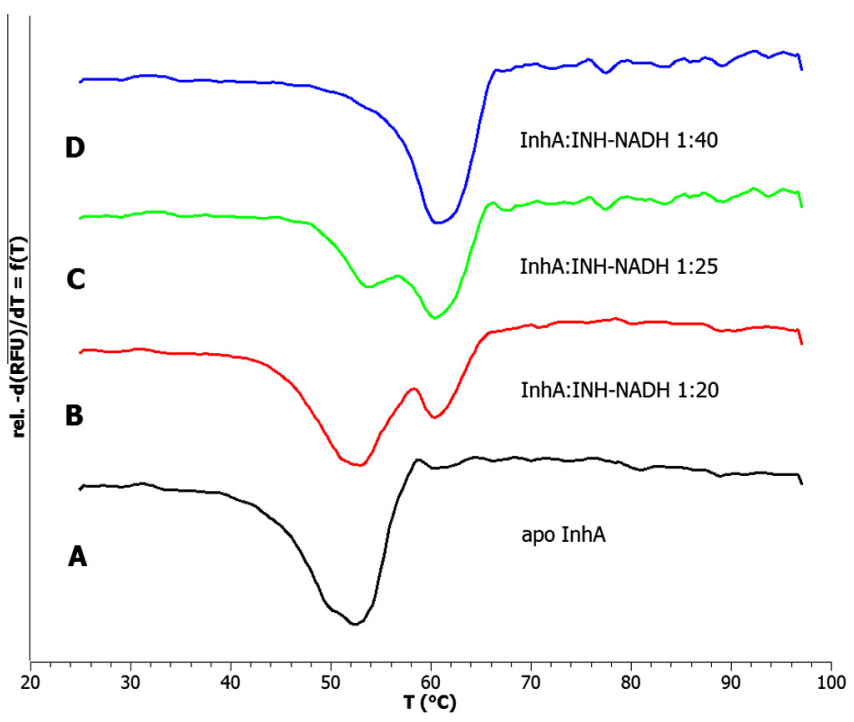

Fig.4. Titration assays of InhA protein $(5 \mathrm{mM})$ with various ratio InhA:INH-NADH Representative curves of the derivative of the relative fluorescence versus temperature $((-d(\mathrm{RFU}) / d T)$, as obtained in DSF experiments, are represented.

\subsection{Titration of INH-NADH adduct to apo InhA}

In order to highlight a potential dose-response relationship, differential scanning fluorimetry experiments were performed with the InhA apo protein at $5 \mu \mathrm{M}$ in the presence of increasing amounts of INH-NADH (from stoichiometric molar ratio to a 500-fold molar excess of INH-NADH), and in the presence of 5\% DMSO. The InhA protein displayed two major melting temperatures depending on whether the protein is in its DMSO destabilized form $\left(T_{\mathrm{m}}=52.8^{\circ} \mathrm{C}\right)$ or in complex with the INH-NADH adduct in a molar ratio $1: 500\left(T_{\mathrm{m}}=63.2^{\circ} \mathrm{C}\right)$ (Table 2, Figs. 4 and S3). A transition state was observed with two thermal shifts corresponding to a molar ratio InhA:INH-NADH between 1:20 and 1:25 (Fig. 4). These results suggest a slow equilibrium between the apo-protein and the INHNADH bound form of InhA, which correlates with the slow-binding inhibition described by Rawat et al., 2003.

\subsection{Crystal structure of apo-InhA}

Crystals of apo-InhA were obtained in 30\% (w/v) PEG 400, $0.1 \mathrm{M}$ sodium acetate and $0.1 \mathrm{M}$ MES buffer, at $\mathrm{pH} 6.5$ and $12{ }^{\circ} \mathrm{C}$. These monoclinic crystals belonged to space group $C 2$ and diffracted up to $1.80 \AA$ (Table 1). There are 6 molecules in the asymmetric unit. InhA is a tetrameric enzyme; four of the six molecules of the asymmetric unit build one tetramer, which obeys the classical 222 symmetry, the remaining 2 molecules are part of a tetramer built from the space group symmetry. Each protomer displays the canonical fold of enoyl-ACP reductase, with a central Rossmann fold domain, and an additional $\beta$-strand and $3 \alpha$-helices (Fig. 5). Helix h5 of the Rossmann fold carries residues Lys165 and Tyr158, which were identified as crucial for the molecular mechanism of InhA (Quémard et al., 1995; Parikh et al., 1999). The active site of InhA is buried in a deep crevice delineated on one side by strands $\mathrm{s} 4$ and s5 and helix h5 from the Rossmann fold and on the other side with helices $\mathrm{h} 6$ and $\mathrm{h} 7$ from the additional domain (Figs. 5 and 6A). Residues 195-207 are highly disordered in 5 of the 6 molecules in the asymmetric unit, to the point that the associated electron density was not interpretable. In the sixth molecule, this region is stabilized by interactions with a symmetry related molecule, and residues 195-207 form $\alpha$-helix h6. In the crystal structure of the apo-form of the S94A mutant of InhA (Dias et al., 2007), this stretch of residues is structured in the 4 molecules of the asymmetric unit. In this triclinic crystal form, molecules of neighboring unit cells contribute to the stabilization of this region for the four protomers of the tetramer. The observed structural flexibility of the segment encompassing residues 195-207 would help to accommodate the entry of the NADH cofactor in the active site in order to form the active enzyme, as well as of the substrate (Rozwarski et al., 1999). This region was identified as being a key factor in the mechanism of action of slow onset inhibitors (Luckner et al., 2010).

\subsection{Crystal structure of InhA in the presence of NADH and INH-NADH adduct}

Crystals of InhA with NADH were obtained by co-crystallization. After a $2 \mathrm{~h}$ incubation of InhA with a 100 -fold molar excess of $\mathrm{NADH}$ and concentration to $10 \mathrm{mg} / \mathrm{mL}$, the solution was mixed with $8-10 \%(\mathrm{v} / \mathrm{v}) \mathrm{MPD}, 0.1 \mathrm{M}$ sodium citrate and $0.1 \mathrm{M}$ HEPES buffer, pH 7.5 at $20^{\circ} \mathrm{C}$. Crystals were obtained within a few days. Crystals were either used for data collection after being cryocooled in a gaseous nitrogen flux at $100 \mathrm{~K}$, or for soaking for $1 \mathrm{~h}$ with a pool of INH-NADH adducts obtained by manganese pyrophosphate activation (Nguyen et al., 2002). Soaking was performed in the crystallization solution supplemented with $8 \mathrm{mM}$ INH-NADH adduct and $16 \%$ DMSO for $1 \mathrm{~h}$ at $20^{\circ} \mathrm{C}$. Crystals were then cryo-cooled as described above. Crystals obtained with 

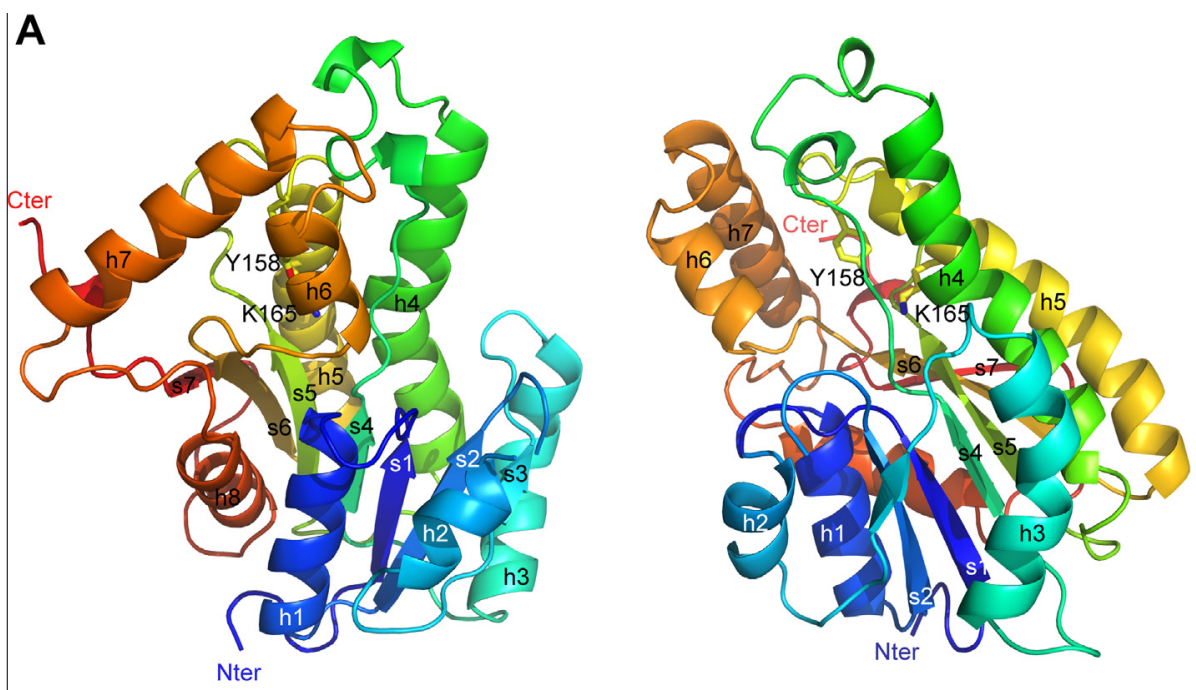

B

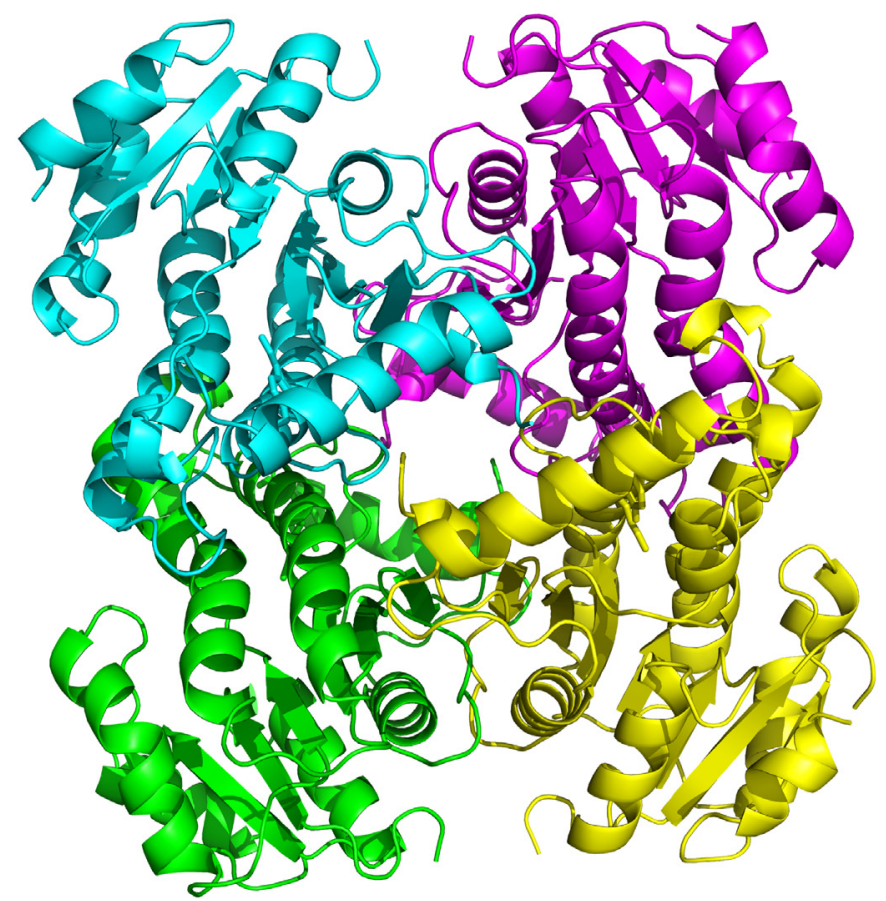

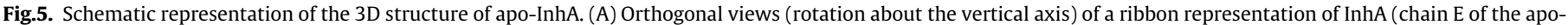

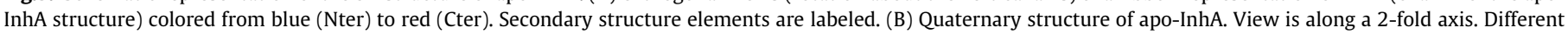
colors are used for each chain.

NADH or with INH-NADH adduct were hexagonal and belonged to space group $P 6_{2} 22$, with one molecule per asymmetric unit. They diffracted to 1.95 and $1.40 \AA$, respectively (Table 1 ).

The NADH moiety binds to InhA in an orientation almost perpendicular to the $\beta$-strands of the Rossmann fold (Fig. 6B), the nicotinamide part of the molecule being buried in the active site. Binding of NADH induces the displacement of the side chain of Tyr158 from the position observed in the structure of apo-InhA (Fig. 6A and B). In the apo-structure, Tyr158 displays two conformations, one being sandwiched between Met161 and Phe149 and pointing toward the active site in the direction of Lys165, the other with the side chain pointing outside the active site, as the result of a $80^{\circ}$ rotation around the $\chi 1$ dihedral angle (Fig. 6A). This latter conformation is the only one observed in the presence of NADH (Figs. $6 \mathrm{~B}$ and 7A). However, this movement is probably not directly induced by the binding of NADH but rather by the presence of a MPD molecule arising from the crystallization medium. Indeed, both conformations of Tyr158 observed in the apo structure would be compatible with the binding of NADH. The presence of this MPD molecule is also responsible for the conformational change of Met199. Binding of NADH also induces structural modifications of Ile16, Ser20, Phe41 and Ile95 (Figs. 6A and 7A). Main-chain atoms of Ile16 are displaced by about $0.9 \AA$, and its side chain is reoriented ( $\chi 1$ is modified by $\left.110^{\circ}\right)$ in order to accommodate the phosphate-ribose moiety of $\mathrm{NADH}$. The movement of Ile16 drives the reorientation of the side chain of Ser20 ( $\chi 1$ is modified by $\left.130^{\circ}\right)$ in order to form a hydrogen bond with the main-chain nitrogen atom of Ile16 and with the oxygen atom of the phosphate group of NADH (Fig. 6B and S4). Last, the position of Phe41 and Ile95 are affected upon binding of NADH. On one hand, Phe41 moves toward NADH, in order to form a stacking interaction with the adenine moiety of NADH, and on the other hand, Ile95 is pushed away from the adenine ring (Fig. 7A). The movement of Phe41 induces small perturbations of residues 40- 
A
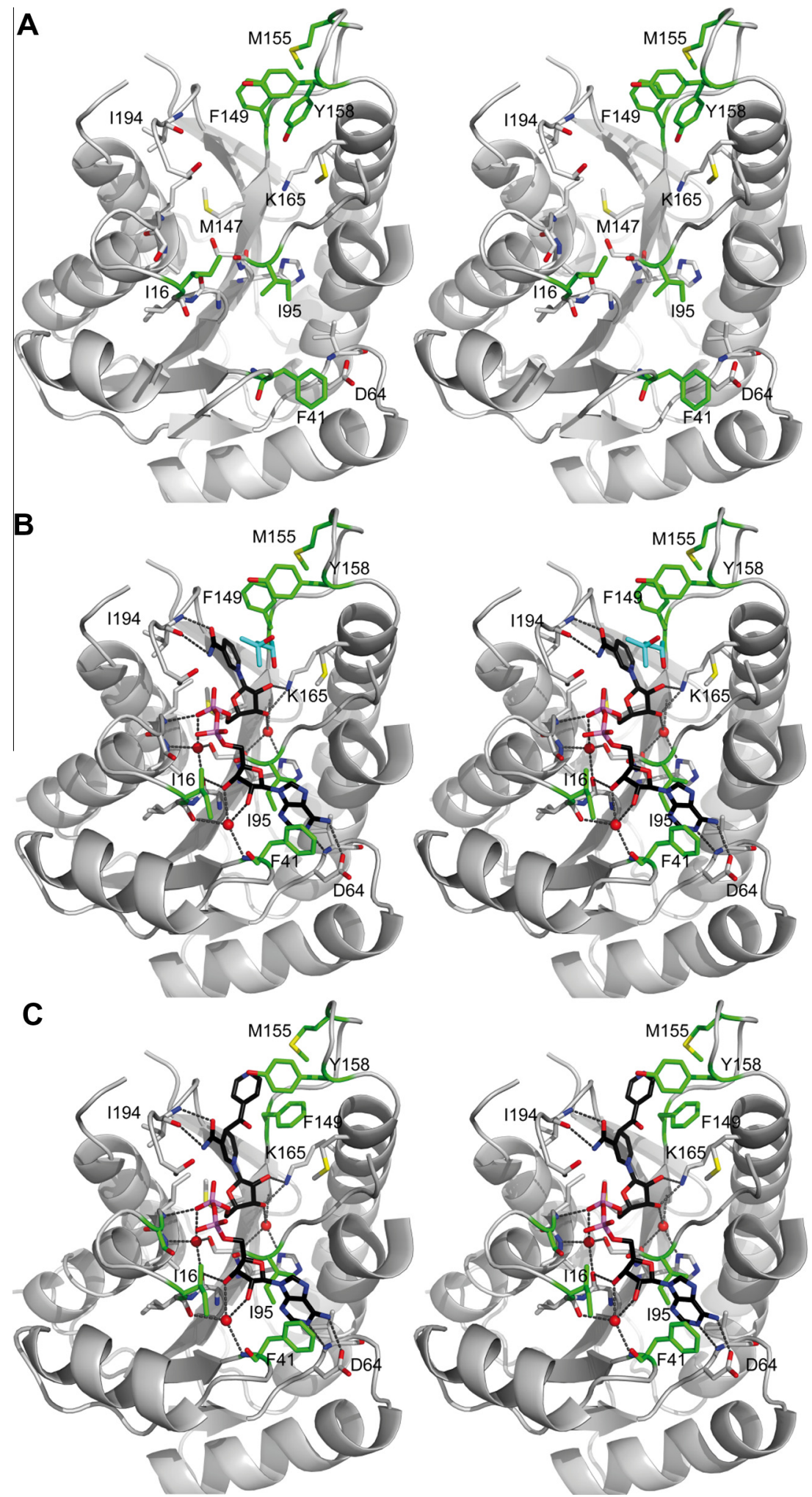

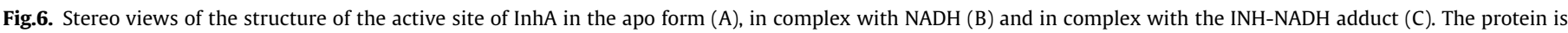

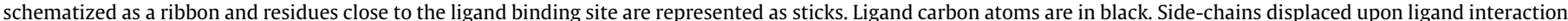

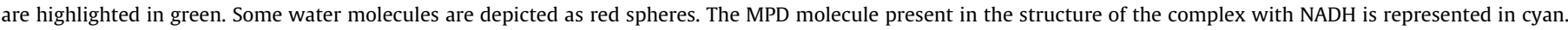
Hydrogen bonds are represented with grey dotted lines. Enlarged and detailed images are provided in Fig. S4.

44, which result in the flipping of the peptide bonds Phe41-Asp42 and Asp42-Arg43.

Crystal structures of InhA in the presence of the INH-NADH adduct have been reported previously (Rozwarski et al., 1998;
Dias et al., 2007; Vilchèze et al., 2006). In the structures of wildtype InhA available within the PDB, adduct was formed in the presence of $\mathrm{MnCl}_{2}, \mathrm{O}_{2}$, NADH, INH and InhA. According to Rozwarski et al. (1998), the presence of InhA is mandatory for the formation 

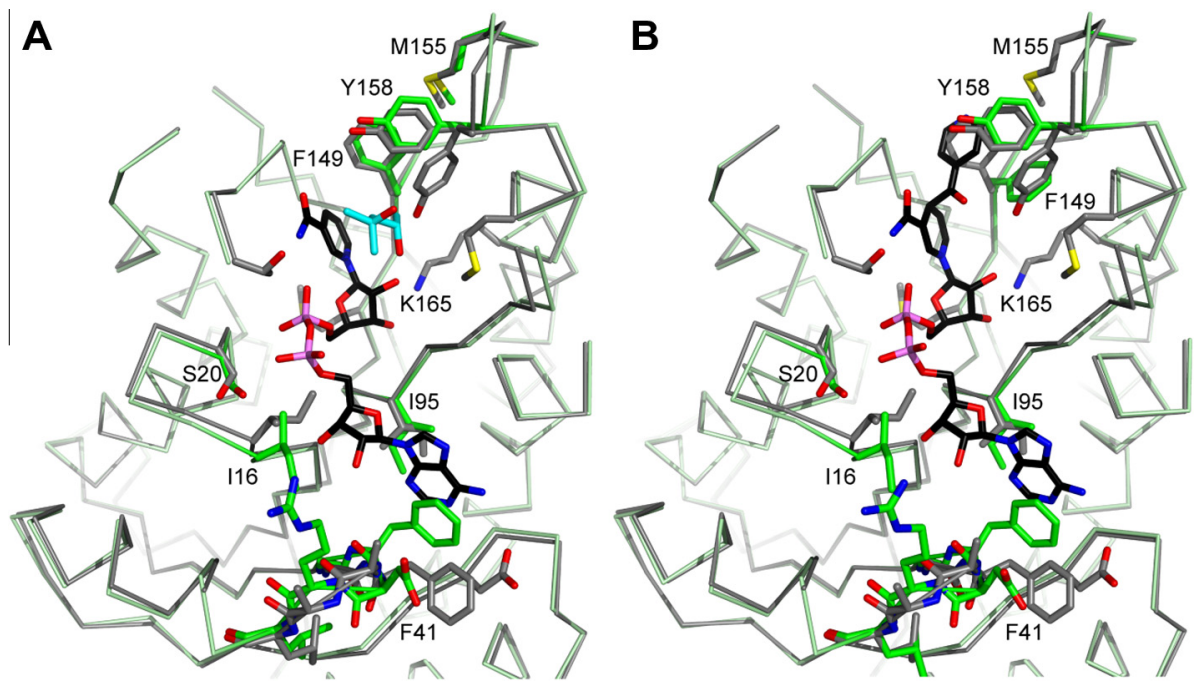

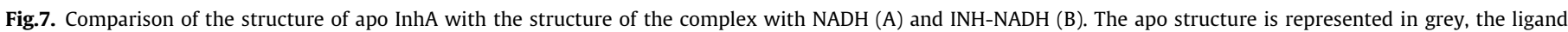

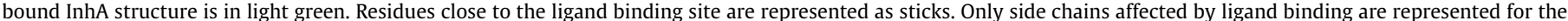

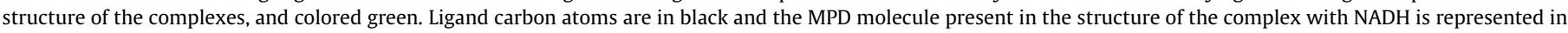
cyan.

of the INH-NADH adduct, as it is not formed in the absence of InhA. Based on these results, the authors proposed that INH is oxidized inside Mtb by KatG and that the adduct would be formed exclusively within the active site of InhA and not in solution nor within KatG, most likely by recombination of the isonicotinoyl radical with a NAD radical generated from NADH. However, it was subsequently shown that the INH-NADH adduct could also be prepared by the direct addition of the highly reactive isonicotinoyl radical to $\mathrm{NAD}^{+}$and that it could inhibit InhA with a $K_{i}$ of about $100 \mathrm{nM}$ (Wilming and Johnsson, 1999). To verify that the adduct formed outside InhA was able to replace the InhA cofactor (NADH) and occupy the corresponding active site of InhA, we generated a pool of INH-NADH adducts (open and cyclic forms, Fig. 3) through biomimetic oxidative activation of INH by action of manganese pyrophosphate in the presence of $\mathrm{NAD}^{+}$, but in the absence of InhA, as previously described (Nguyen et al., 2001a, 2002). A crystal of InhA-NADH was soaked for $1 \mathrm{~h}$ in a purified solution of the pool of INH-NADH adducts, containing the cyclic hemiamidal adducts $\mathbf{2}$ as well as the open keto-amides $\mathbf{1}$ (Fig. 3 ). These crystals diffracted up to $1.40 \AA$ resolution (Table 1 ). The initial electron density showed that the INH-NADH adduct was present in the active site (Fig. 8), which confirmed that the INH-NADH adduct is able to take the place of NADH and its formation does not require InhA assistance. The electron density is compatible with the open keto-amide adduct $\mathbf{1}$ with the $4 S$ configuration, as previously observed (Rozwarski et al., 1998; Dias et al., 2007), and no cyclic tautomers (2, Fig. 3) could be identified (Fig. 8). When the refinement progressed, it appeared that Phe149 occupied alternative conformations (Fig. S5), with one conformation not compatible with the presence of INH-NADH, the other conformation corresponding to what was observed in both InhA apo and InhANADH structures (Fig. S5). Refinement of relative occupancy indicated that indeed both NADH and INH-NADH compounds were present with half occupancies (Fig. 7). Hence, soaking with INH$\mathrm{NADH}$ adduct during one hour allowed displacing about $50 \%$ of bound NADH in the NADH-InhA crystal.

All the structural adaptions of InhA to NADH are also observed in the presence of INH-NADH (Fig. 7). In addition to these, the accommodation of the INH-NADH adduct induced the displacement of the phenyl group of Phe149, through a rotation of $130^{\circ}$ around the $\chi 1$ torsion angle, compared to its position observed in the InhA-NADH complex and in the InhA apo (Figs. 6C and 7B). This structural modification is propagated to Met155, whose $C \alpha$ is pushed $0.45 \AA$ away. Therefore, in the crystal structure obtained after soaking with INH-NADH, two conformations of the enzyme are observed: the NADH bound conformation and a INH-NADH bound conformation that differs only by the position of Phe149 and Met155, which display alternate conformation (Fig. S2). It is worth noting that the location in the active site of InhA of the INH-NADH adduct, pre-formed by a biomimetic approach (i.e. in the absence of InhA), is identical to that of the adduct produced in the biological conditions (i.e. in the presence of InhA) (Rozwarski et al., 1999).

Although the soaking was performed with a mixture of open keto-amide adducts $\mathbf{1}$ and cyclic hemiamidal adducts $\mathbf{2}$, the electron density only accounts for the binding of the open ketoamide adduct 1 with the $4 S$ configuration (Fig. 8). If binding of the cyclic hemiamidal had occurred, it would have only been with such a low occupancy that no associated electron density could be seen. Hence, one can propose that the keto-amide adduct has more affinity for InhA than the cyclic hemiamidal adduct and as these two adducts are in equilibrium (Stigliani et al., 2008), the cyclic adduct is progressively converted in solution into the open adduct as the latter is sequestered in the active site of InhA. Another plausible explanation would be that the cyclic hemiamidal adduct could interact with the active site of InhA but rapidly undergo a catalytic opening toward the more stable open keto-amide adduct (Stigliani et al., 2008). Thus, our results showed that the INH-NADH adduct, which have been formed outside InhA, can indeed penetrate into the catalytic site of InhA displacing the NADH cofactor (Wilming and Johnsson, 1999) and that this interaction is highly specific to the keto-amide adduct with the $4 S$ configuration. These results are in agreement with the previous hypothesis of Wilming and Johnsson (1999).

\section{Conclusion}

We report for the first time the crystal structure of the apo-form of the wild-type InhA at $1.80 \AA$. The apo-InhA structure can serve as a reference structure for comparison to the liganded structures 

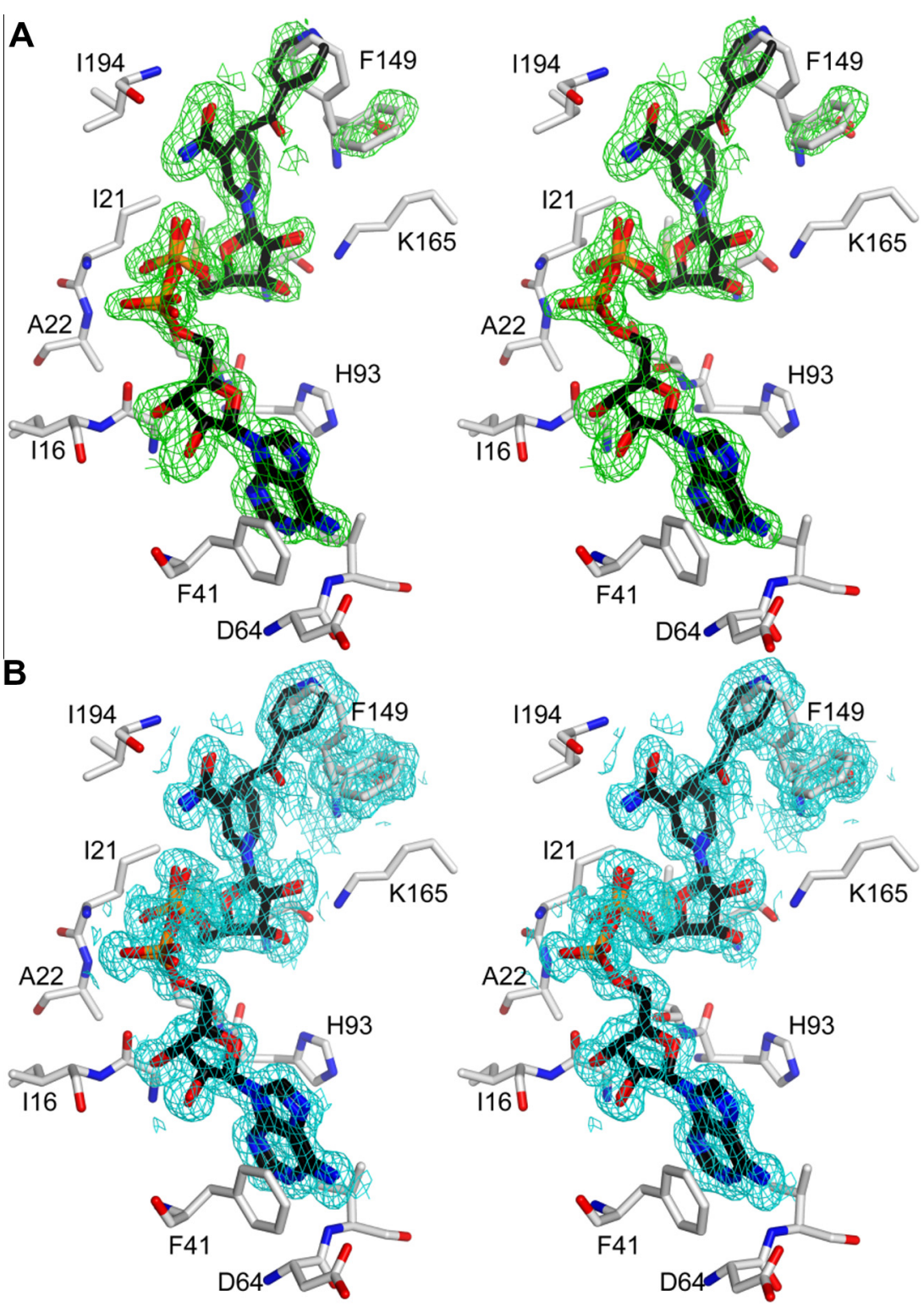

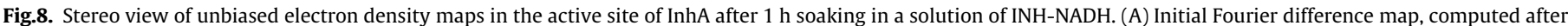

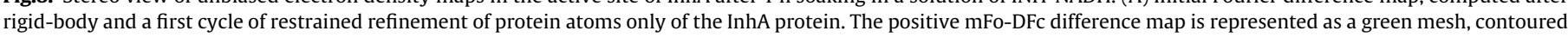

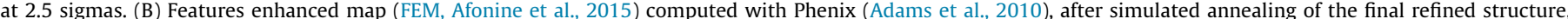

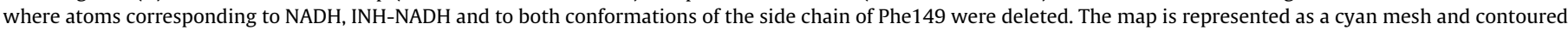
at 1 sigma. The refined structure of InhA in complex with NADH-INH is displayed. Proteins atoms are represented in grey and ligand carbon atoms are colored black.

and can disclose the conformational changes caused by ligand binding. It is of great importance to analyze whether the significant structural changes of a protein structure occur upon protein ligand interactions. This in the context of its utilization as a tool for prediction approaches in drug discovery.

We have also demonstrated through DSF and crystallographic studies, that a INH-NADH adduct formed in the absence of InhA was able to displace the cofactor NADH in the complex InhA:NADH, This shows that, in vitro, the INH-NADH adduct does not necessarily need InhA to be formed and, that, once formed outside InhA, it is able to bind to the protein. However, as the in vitro conditions are very far from the situation in vivo, this work cannot completely exclude that adduct formation occurs differently within the bacterium. In addition, soaking experiments with the pool of adducts preformed by a biomimetic approach demonstrated that only the open keto-amide $\mathbf{1}$ (configuration $4 S$ ) was found inside the crystal structure of InhA:adduct. These results showed a high level of specificity of interaction and the adduct 1 in a configuration $4 R$, does not seem to play any significant role in the inhibition of InhA.

\section{Acknowledgments}

We thank Dr John Blanchard for the generous gift of the pET15b/inhA plasmid. We acknowledge SOLEIL for provision of synchrotron radiation facilities and we would like to thank Dr. Pierre Legrand for assistance in using beamline PROXIMA 1 at SOLEIL. Differential scanning fluorimetry and macromolecular crystallography equipment used in this study are part of the Integrated Screening Platform of Toulouse (PICT, IBiSA). 


\section{Appendix A. Supplementary data}

Supplementary data associated with this article can be found, in the online version, at http://dx.doi.org/10.1016/j.jsb.2015.04.008.

\section{References}

Adams, P.D., Afonine, P.V., Bunkóczi, G., Chen, V.B., Davis, I.W., Echols, N., Headd, J.J. Hung, L.-W., Kapral, G.J., Grosse-Kunstleve, R.W., McCoy, A.J., Moriarty, N.W. Oeffner, R., Read, R.J., Richardson, D.C., Richardson, J.C., Terwilliger, T.C., Zwart, P.H., 2010. PHENIX: a comprehensive Python-based system for macromolecular structure solution. Acta Crystallogr. D Biol. Crystallogr. 66, 213-221.

Argyrou, A., Vetting, M.W., Blanchard, J.S., 2007. New insight into the mechanism of action of and resistance to isoniazid: interaction of Mycobacterium tuberculosis enoyl-ACP reductase with INH-NADP. J. Am. Chem. Soc. 129, 9582-9583.

Banerjee, A., Dubnau, E., Quémard, A., Balasubramanian, V., Um, K.S., Wilson, T., Collins, D., de Lisle, G. Jacobs Jr., W.R., 1994. InhA, a gene encoding a target for isoniazid and ethionamide in Mycobacterium tuberculosis. Science 263, 227-230.

Bernardes-Génisson, V., Deraeve, C., Chollet, A., Bernadou, J., Pratviel, G., 2013 Isoniazid: an update on the multiple mechanisms for a singular action. Curr. Med. Chem. 20, 4370-4385.

Bricogne, G., Blanc, E., Brandl, M., Flensburg, C., Keller, P., Paciorek, W., Roversi, P. Sharff, A., Smart, O.S., Vonrhein, C., Womack, T.O., 2011. BUSTER Version 2.10.0. Global Phasing Ltd, Cambridge, United Kingdom.

Broussy, S., Coppel, Y., Nguyen, M., Bernadou, J., Meunier, B., 2003. ${ }^{1} \mathrm{H}$ and ${ }^{13} \mathrm{C}$ NMR characterization of hemiamidal isoniazid- $\mathrm{NAD}(\mathrm{H})$ adduct as possible inhibitors of InhA reductase of Mycobacterium tuberculosis. Chem. Eur. J. 9, 2034-2038.

Cegielski, J.P., 2010. Extensively drug-resistant tuberculosis: "there must be some kind of way out of here". Clin. Infect. Dis. 50, S195-S200.

Davidson, L.A., Takayama, K., 1979. Isoniazid inhibition of the synthesis of the monosaturated long-chain fatty acid in Mycobacterium tuberculosis H37Ra. Antimicrob. Agents Chemother. 16, 104-105.

Dessen, A., Quémard, A., Blanchard, J.S., Jacobs Jr., W.R., Sacchettini, J.C., 1995 Crystal structure and function of the isoniazid target of Mycobacterium tuberculosis. Science 267, 1638-1641.

Dias, M.V.B., Vasconcellos, I.B., Prado, A.M.X., Fadel, V., Basso, L.A., de Azevedo, W.F. Santos Jr., D.S., 2007. Crystallographic studies on the binding of isonicotinoylNAD adduct to wild type and isoniazid resistant 2-trans-enoyl-ACP (CoA) reductase from Mycobacterium tuberculosis. J. Struct. Biol. 159, 369-380.

Emsley, P., Cowtan, K., 2004. Coot: model-building tools for molecular graphics. Acta Crystallogr. D Biol. Crystallogr. 60, 2126-2132.

Hartkoorn, R.C., Sala, C., Neres, J., Pojer, F., Magnet, S., Mukherjee, R., Uplekar, S., Boy-Röttger, S., Altmann, K.H., Cole, S.T., 2012. Towards a new tuberculosis drug: pyridomycin - nature's isoniazid. EMBO Mol. Med. 4, 1032-1042.

Hartkoorn, R.C., Pojer, F., Read, J.A., Gingell, H., Neres, J., Horlacher, O.P., Altmann, K.H., Cole, S.T., 2014. Pyridomycin bridges the NADH- and substrate-binding pockets of the enoyl reductase InhA. Nat. Chem. Biol. 10, 96-98.

Jörnvall, H., Persson, B., Krook, M., Atrian, S., Gonzàlez-Duarte, R., Jeffery, J., Ghosh, D., 1995. Short-chain dehydrogenases/reductases (SDR). Biochemistry 34, 6003-6013.

Kabsch, W., 2010. XDS. Acta Crystallogr. D Biol. Crystallogr. 66, 125-132.

Kuo, M.R., Morbidoni, H.R., Alland, D., Sneddon, S.F., Gourlie, B.B., Staveski, M.M., Leonard, M., Gregory, J.S., Janjigian, A.D., Yee, C., Musser, J.M., Kreiswirth, B. Iwamoto, H., Perozzo, R., Jacobs Jr., W.R., Sacchettini, J.C., Fidock, D.A., 2003. Targeting tuberculosis and malaria through inhibition of enoyl reductase: compound activity and structural data. J. Biol. Chem. 278, 20851-20859.

Lei, B., Wei, C.J., Tu, S.C., 2000. Action mechanism of antitubercular isoniazid. J. Biol. Chem. 275, 2520-2526.

Lu, X.Y. You, Q.D., Chen, Y.D., 2010. Recent progress in the identification and development of InhA direct inhibitors of Mycobacterium tuberculosis. Mini Rev. Med. Chem. 10, 182-193.

Luckner, S.R., Liu, N., am Ende, C.W., Tonge, P.J., Kisker, C., 2010. A slow, tight binding inhibitor of InhA, the enoeyl-acyl carrier protein reductase from Mycobacterium tuberculosis. J. Biol. Chem. 585, 14330-14337.

Moir, D.T., 2005. Identification of inhibitors of bacterial enoyl-acyl carrier protein reductase. Curr. Drug Targets Infect. Disord. 5, 297-305.

Molle, V., Gulten, G., Vilchèze, C., Veyron-Churlet, R., Zanella-Cléon, I., Sacchettini, J.C., Jacobs Jr., W.R., Kremer, L., 2010. Phosphorylation of InhA inhibits mycolic acid biosynthesis and growth of Mycobacterium tuberculosis. Mol. Microbiol. 78, 1591-1605.

Murshudov, G.N., Shubak, P., Lebedev, A.A., Pannu, N.S., Steiner, R.A., Nicholls, R.A. Winn, M.D., Long, F., Vagin, A.A., 2011. REFMAC5 for the refinement of macromolecular structures. Acta Crystallogr. D Biol. Crystallogr. 67, 355-367.

Nguyen, M., Claparols, C., Bernadou, J., Meunier, B., 2001a. A fast and efficient metal mediated oxidation and identification of isoniazid-NAD $(\mathrm{H})$ adducts ChemBioChem, 877-883.

Nguyen, M., Quémard, A., Marrakchi, H., Bernadou, J., Meunier, B., 2001b. The nonenzymatic activation of isoniazid by $\mathrm{Mn}^{\mathrm{III}}$ pyrophosphate in the presence of
NADH produces the inhibition of the enoyl-ACP Reductase InhA from Mycobacterium tuberculosis. C.R. Acad. Sci. Paris Ser. IIc 4, 35-40.

Nguyen, M., Quémard, A., Broussy, S., Bernadou, J., Meunier, B., 2002. Mn ${ }^{\mathrm{III}}$ pyrophosphate as an efficient tool for studying the mode of action of isoniazid on the InhA protein from Mycobacterium tuberculosis. Antimicrob. Agents Chemother. 46, 2137-2143.

Oliveira, J.S., Pereira, J.H., Canduri, F., Rodrigues, N.C., de Souza, O.N., de Azevedo, W.F., Basso Jr., L.A., Santos, D.S., 2006. Crystallographic and pre-steady-state kinetics studies on binding of NADH to wild-type and isoniazid-resistant enoyl$\mathrm{ACP}(\mathrm{Co} A)$ reductases enzymes from Mycobacterium tuberculosis. J. Mol. Biol. 359, 646-666.

Parikh, S., Moynihan, D.P., Xiao, G., Tonge, P.J., 1999. Role of tyrosine 158 and lysine 165 in the catalytic mechanism of InhA, the enoyl-ACP reductase from Mycobacterium tuberculosis. Biochemistry 38, 13623-13634.

Pavel, V.A., Moriarty, N.W., Mustyakimov, M., Sobolev, O.V., Terwilliger, T.C., Turk, D., Urzhumtsev, A., Adams, P.D., 2015. FEM: features-enhanced maps. Acta Crystallogr. D Biol. Crystallogr. 71, 646-666.

Quémard, A., Sacchettini, J.C., Dessen, A., Vilchèze, C., Bittman, R., Jacobs Jr., W.R., Blanchard, J.S., 1995. Enzymatic characterization of the target for isoniazid in Mycobacterium tuberculosis. Biochemistry 34, 8235-8241.

Rawat, R., Whitty, A., Tonge, P.J., 2003. The isoniazid-NAD adduct is a slow, tightbinding inhibitor of InhA, the Mycobacterium tuberculosis enoyl reductase: adduct affinity and drug resistance. Proc. Natl. Acad. Sci. U.S.A. 100, 1388113886.

Rozwarski, D.A., Grant, G.A., Barton, D.H.R., Jacobs Jr., W.R., Sacchettini, J.C., 1998. Modification of the NADH of the isoniazid target (InhA) from Mycobacterium tuberculosis. Science 279, 98-101.

Rozwarski, D.A., Vilchèze, C., Sugantino, M., Bittman, R., Sacchettini, J.C., 1999. Crystal structure of the Mycobacterium tuberculosis enoyl-ACP reductase, InhA, in complex with $\mathrm{NAD}^{+}$and a C16 fatty acyl substrate. J. Biol. Chem. 274, 1558215589.

Stigliani, J.L., Arnaud, P., Delaine, T., Bernardes-Génisson, V., Meunier, B., Bernadou, J. 2008. Binding of the tautomeric forms of isoniazid-NAD adducts to the active site of the Mycobacterium tuberculosis enoyl-ACP reductase (InhA): a theoretical approach. J. Mol. Graph. Model. 27, 536-545.

Sullivan, T.J., Truglio, J.J., Boyne, M.E., Novichenok, P., Zhang, X., Stratton, C.F., Li, H.J., Kaur, T., Amin, A., Johnson, F., Slayden, R.A., Kisher, C., Tonge, P.J., 2006. High affinity InhA inhibitors with activity against drug resistant strains of Mycobacterium tuberculosis. ACS Chem. Biol. 1, 43-53.

Takayama, K., Wang, L., David, H.L., 1972. Effect of isoniazid on the in vivo mycolic acid synthesis, cell growth, and viability of Mycobacterium tuberculosis. Antimicrob. Agents Chemother. 2, 29-35.

Takayama, K., Schnoes, H.K., Armstrong, E.L., Boyle, R.W., 1975. Site of inhibitory action of isoniazid in the synthesis of mycolic acids in Mycobacterium tuberculosis. J. Lipid Res. 16, 308-317.

Velayati, A.A., Masjedi, M.R., Farnia, P., Tabarsi, P., Ghanavi, J., Ziazarifi, A.H., Hoffner, S.E., 2009. Emergence of new forms of totally drug-resistant tuberculosis bacilli: super extensively drug-resistant tuberculosis or totally drug-resistant strains in Iran. Chest 136, 420-425.

Vilchèze, C., Wang, F., Arai, M., Hazbon, M.H., Colangeli, R., Kremer, L., Weisbrod, T.R., Alland, D., Sacchettini, J.C., Jacobs Jr., W.R., 2006. Transfer of a point mutation in Mycobacterium Tuberculosis inhA resolves the target of isoniazid. Nat. Med. 12, 1027-1029.

Vonrhein, C., Flensburg C, Keller, P. Sharff, A Smart, O, Paciorek, W. Womack, T, Bricogne, G., 2011. Data processing and analysis with the autoPROC toolbox. Acta Crystallogr. D Biol. Crystallogr. 67, 293-302.

Wang, F., Langley, R., Gulten, G., Dover, L.G., Besra, G.S., Jacobs Jr., W.R., Sacchettini, J.C., 2007. Mechanism of thioamide drug action against tuberculosis and leprosy. J. Exp. Med. 204, 73-78.

Wilming, M., Johnsson, K., 1999. Spontaneous formation of the bioactive form of the tuberculosis drug isoniazid. Angew. Chem. Int. Ed. 38, 2588-2590.

Winder, F.G., Collins, P.B., 1970. Inhibition by isoniazid of synthesis of mycolic acids in Mycobacterium tuberculosis. J. Gen. Microbiol. 63, 41-48.

Winn, M.D., Ballard, C.C., Cowtan, K.D., Dodson, E.J., Emsley, P., Evans, P.R., Keegan, R.M., Krissinel, E.B., Leslie, A.G.W., McCoy, A., McNicholas, S.J., Murshudov, G.N. Pannu, N.S., Potterton, E.A., Powell, H.R., Read, R.J., Vagin, A., Wilson, K.S., 2011. Overview of the CCP4 suite and current developments. Acta Crystallogr. D Biol. Crystallogr. 67, 235-242.

World Health Organization (WHO), 2010. Treatment of Tuberculosis: Guidelines for National Programmes. Geneva. Available at: <http://www.who.int/tb/features archive/new treatment guidelines may2010/en/> (accessed February 2014).

World Health Organization (WHO), 2013. Global Tuberculosis Report. Geneva Available at: <http://www.who.int/tb/publications/global_report/en/> (accessed June 2014).

World Health Organization (WHO), 2013. Multidrug-resistant tuberculosis. Available at: <http://www.who.int/tb/challenges/mdr/mdr_tb_2013_update/ fr> (accessed February 2014).

Zhang, Y.M., White, S.W., Rock, C.O., 2006. Inhibiting bacterial fatty acid synthesis. J. Biol. Chem. 281, 17541-17544. 


\section{Supporting materials}

Crystal Structure of the enoyl-ACP reductase of Mycobacterium tuberculosis (InhA) in the apo-form and in complex with the active metabolite of isoniazid pre-formed by a biomimetic approach.

Aurélien Chollet, Lionel Mourey, Christian Lherbet, Alexandra Delbot, Sylviane Julien, Michel Baltas, Jean Bernadou, Geneviève Pratviel, Laurent Maveyraud*, Vania BernardesGénisson*.

1. Characterization of the synthesized INH-NADH adducts

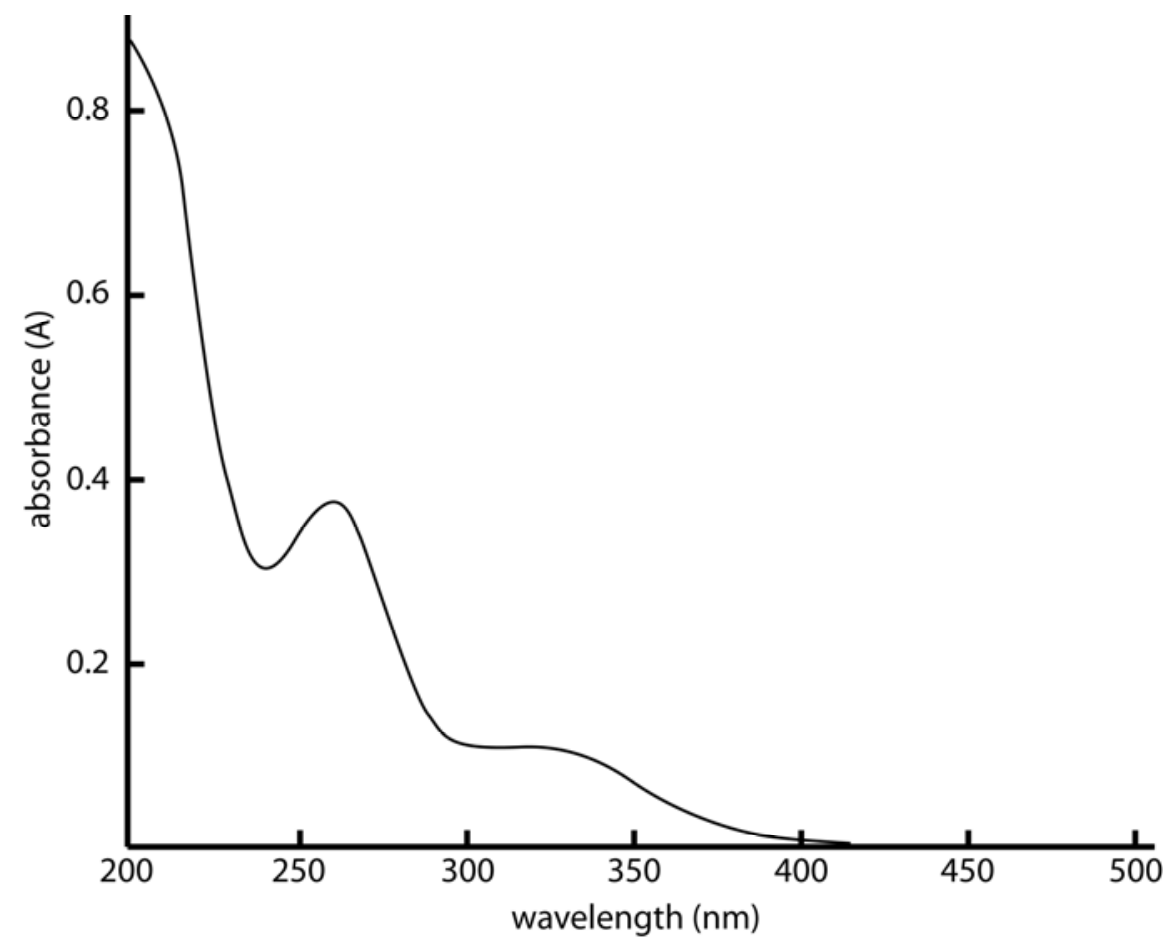

Figure S1: UV-visible spectrum of INH-NADH adduct. The spectrum was collected on a Libra550 spectrophotometer, between 200 and $500 \mathrm{~nm}$ with a $1 \mathrm{~nm}$ step. Two peaks are detected: at $259.0 \mathrm{~nm}$ (Abs=0.377) and $330 \mathrm{~nm}(\mathrm{Abs}=0.108)$. 
A

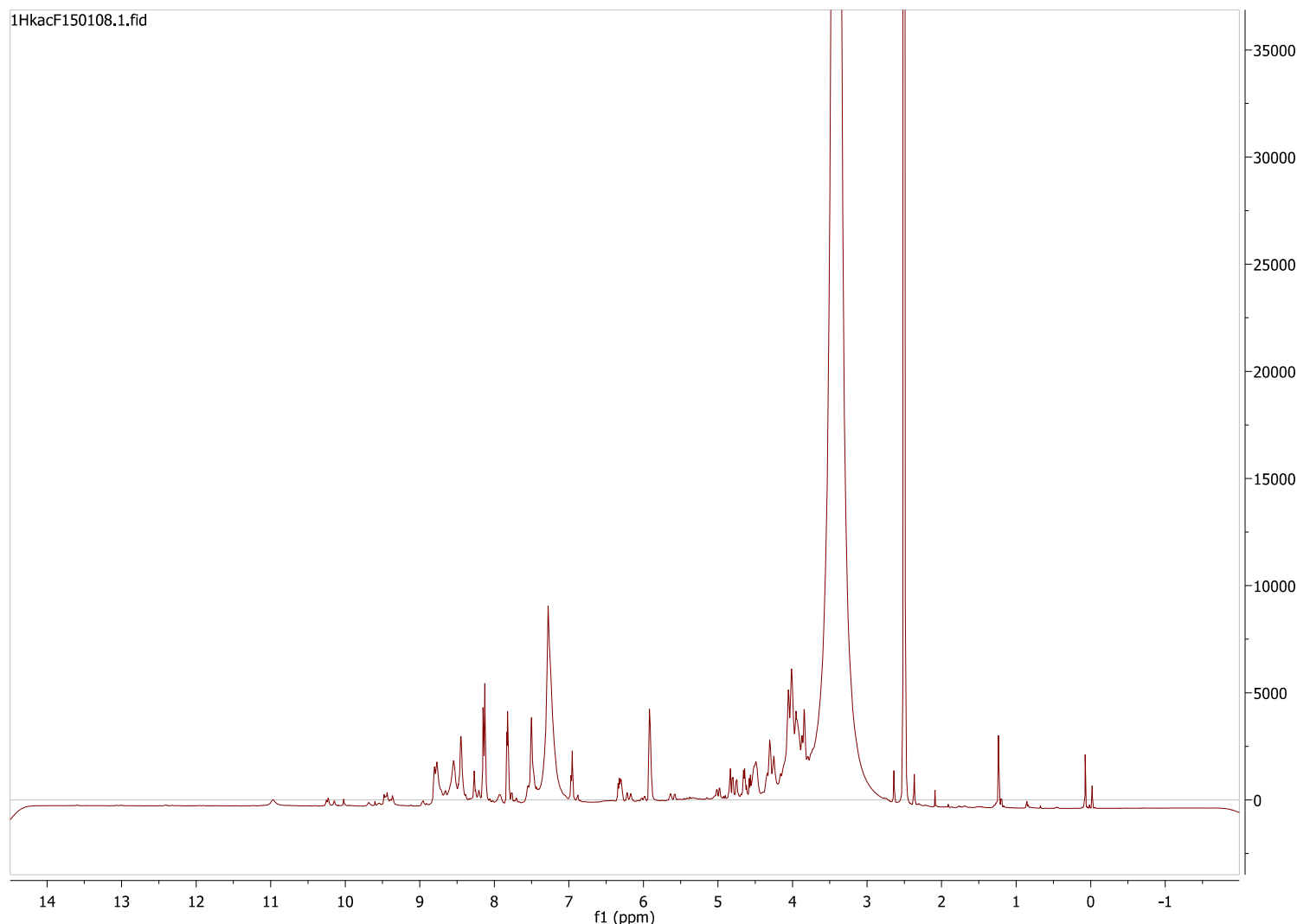


B

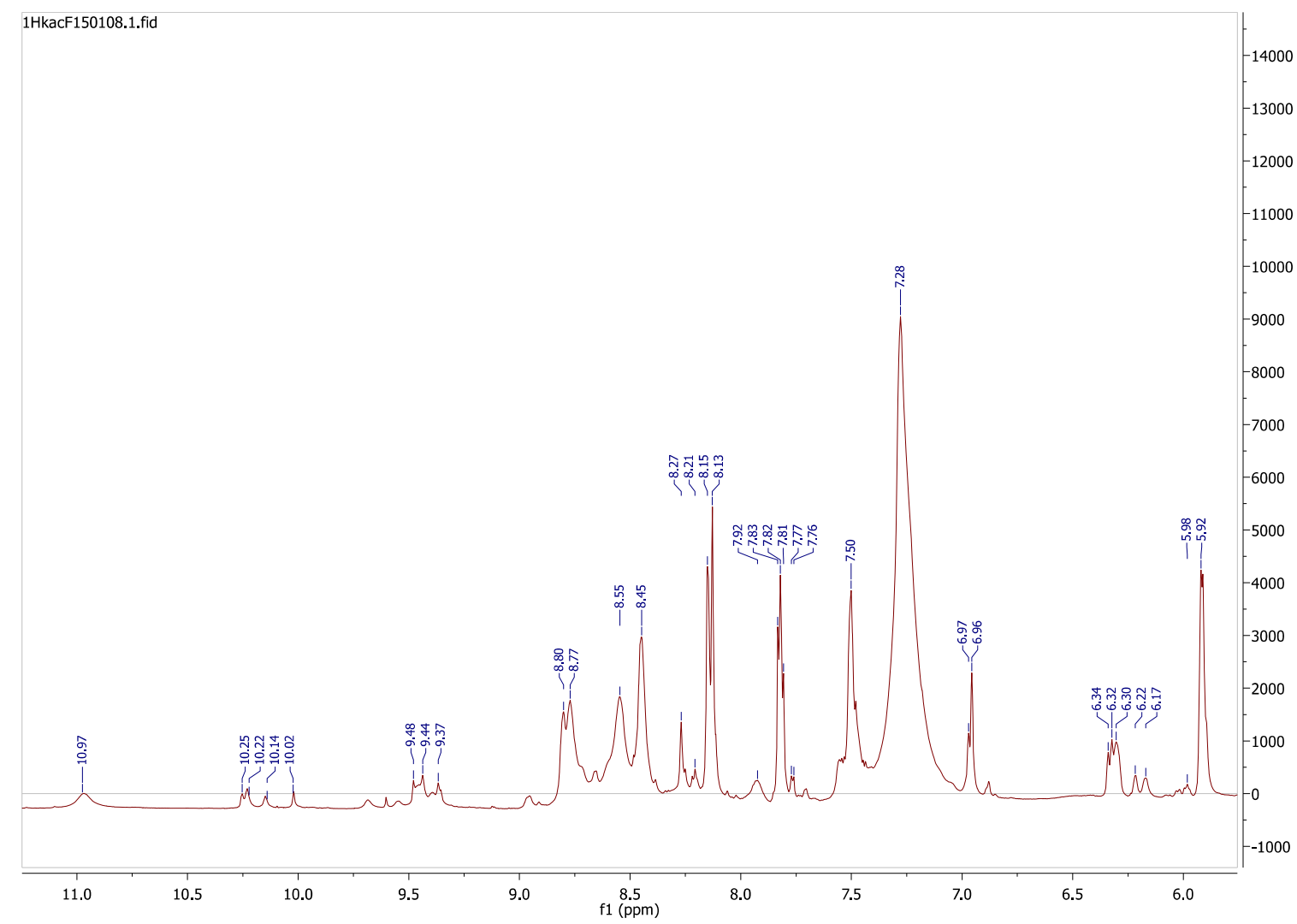


C

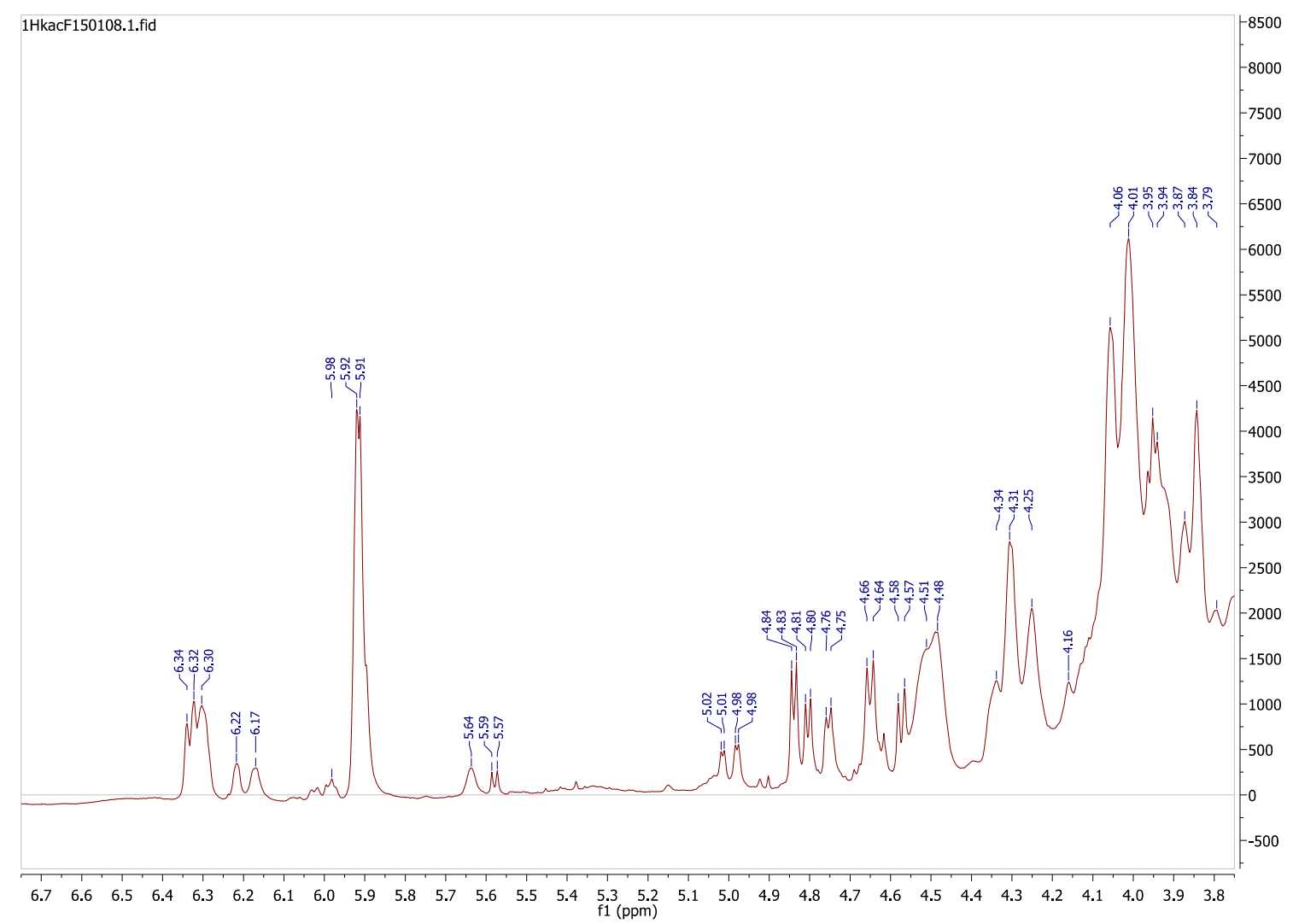

Figure S2: ${ }^{1} \mathrm{H}$ NMR spectrum of INH-NADH (open keto-amide and cyclic hemiamidal adducts) A: between 0 and 14.5 ppm. B: Zoom of the 5.5 - 11.5 ppm region of the ${ }^{1} \mathrm{H}$ NMR spectrum of INHNADH (open keto-amide and cyclic hemiamidal adducts). C: Zoom of the 3.8 - 6.7 ppm region of the ${ }^{1} \mathrm{H}$ NMR spectrum of INH-NADH (open keto-amide and cyclic hemiamidal adducts)

2. Thermostability studies of apo-InhA, in complex with NAD $^{+}$, NADH or INH-NADH 


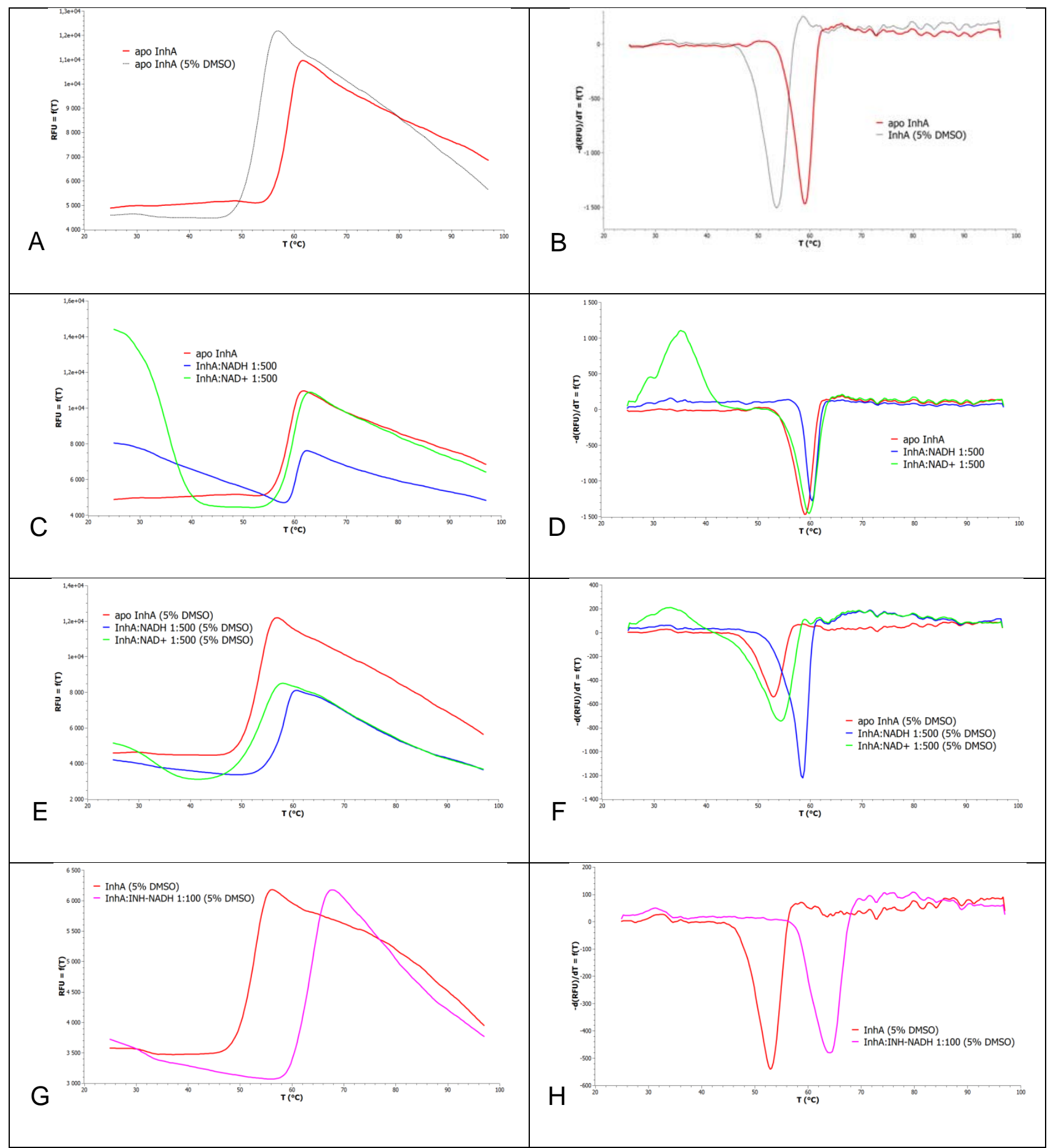

Figure S3: Thermal stability of InhA as evaluated with DSF. Representative curves of relative fluorescence unit versus temperature are shown on the left, as well as their derivative ((-d(RFU)/dT), on the right. Several conditions were evaluated and are compared. A, B: effect of the presence of 5\% DMSO on apo-InhA. C, D: effect of NADH and NAD ${ }^{+}$on InhA in absence of DMSO. E, F: effect of NADH and $\mathrm{NAD}^{+}$on InhA in presence of 5\% DMSO. G, H: effect of INH-NADH on InhA.

\section{Titration of INH-NADH adduct to apo-enzyme}

Table S1. Thermal stability measurement of InhA in the presence of varying quantity of INH-NADH 
adducts

\begin{tabular}{ccc}
$\begin{array}{c}\text { Molar ratio } \\
\text { InhA:INH-NADH } \\
5 \% \text { DMSO }(\mathrm{v} / \mathrm{v})\end{array}$ & $\mathrm{T}_{\mathrm{m}}\left({ }^{\circ} \mathrm{C}\right)$ & $\begin{array}{c}\boldsymbol{\Delta} \mathrm{T}_{\mathrm{m}}\left({ }^{\circ} \mathrm{C}\right) \\
\text { (apoenzyme) }\end{array}$ \\
\hline $1: 0$ & $52.8 \pm 0.5$ & $\mathrm{n} / \mathrm{a}$ \\
\hline $1: 1$ & $53.0 \pm 0.2$ & $0.2 \pm 0.7$ \\
\hline $1: 10$ & $52.8 \pm 0.3$ & $0.0 \pm 0.8$ \\
& $60.0 \pm 0.0$ & $7.2 \pm 0.5$ \\
\hline $1: 20$ & $53.6 \pm 0.7$ & $0.8 \pm 1.2$ \\
& $60.3 \pm 0.0$ & $7.5 \pm 0.5$ \\
\hline $1: 25$ & $53.7 \pm 0.0$ & $0.4 \pm 0.5$ \\
\hline $1: 40$ & $60.3 \pm 0.0$ & $7.5 \pm 0.5$ \\
\hline $1: 50$ & $60.9 \pm 0.3$ & $8.0 \pm .8$ \\
\hline $1: 100$ & $61.2 \pm 0.8$ & $8.4 \pm 1.3$ \\
\hline $1: 200$ & $63.9 \pm 0.0$ & 11.1 \\
\hline $1: 500$ & $63.2 \pm 0.5$ & 10.7 \\
\hline
\end{tabular}

4.

A

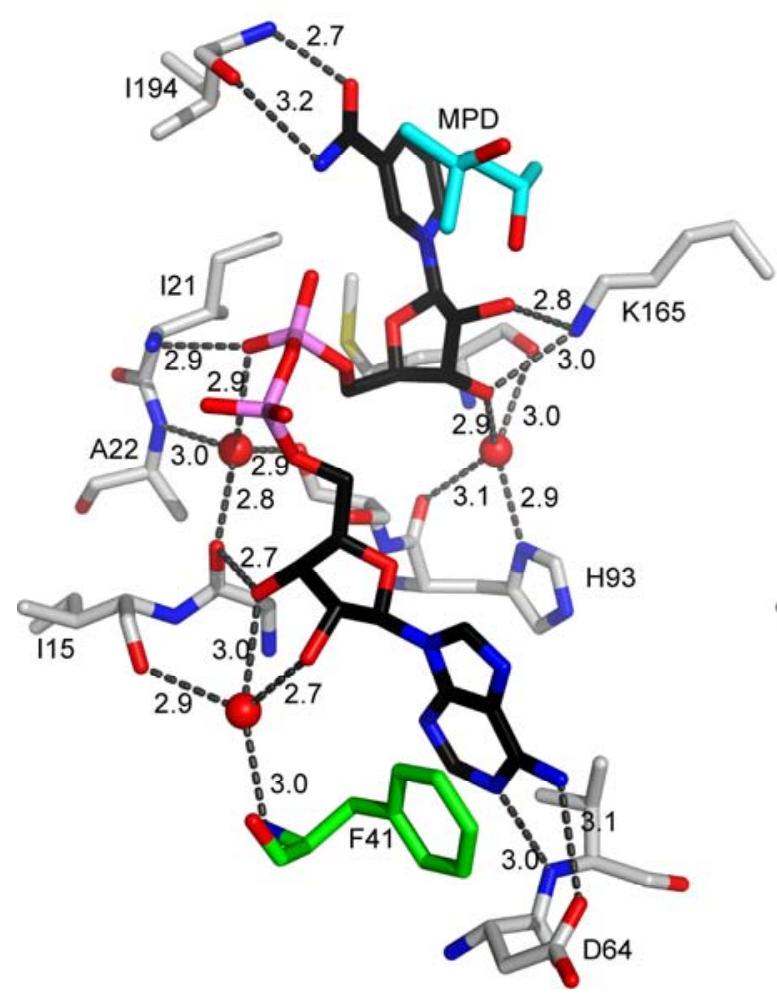

B

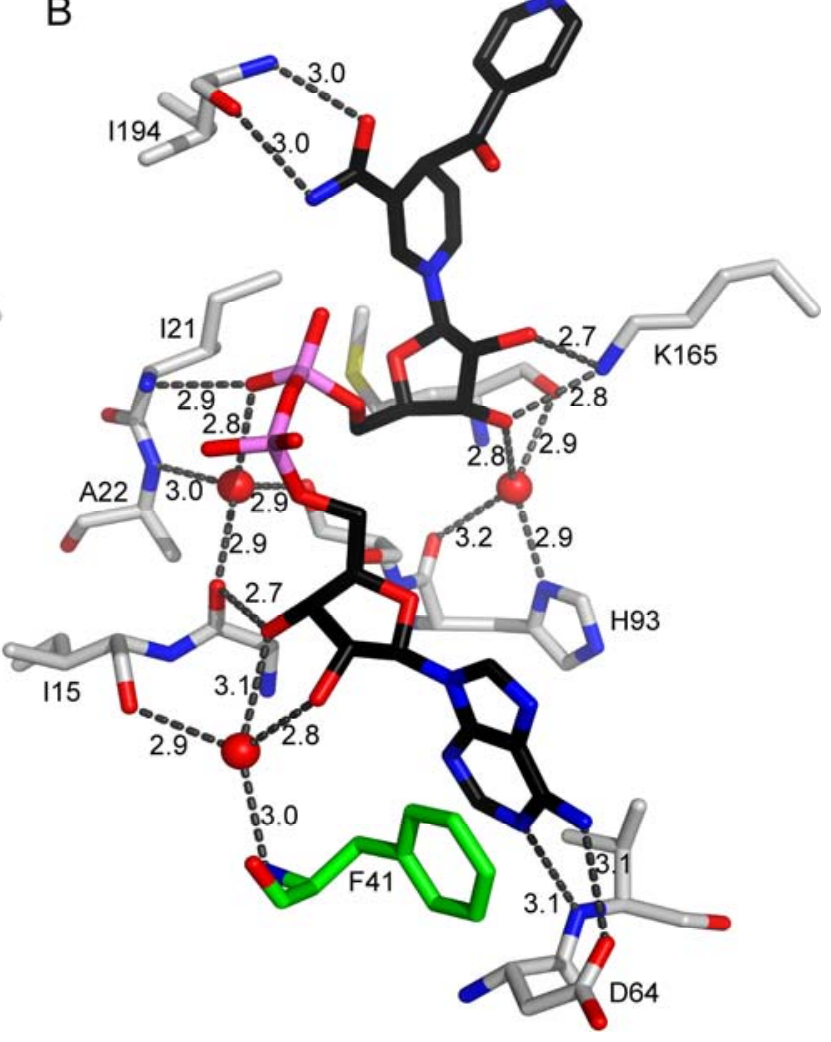


Figure S4: detailed interactions of ligands with residues of the binding site. (A) NADH bound InhA, (B) INH-NADH bound InhA. Protein carbon atoms are colored grey, those of NADH or INHNADH are colored black, and those of MPD are cyan. Water molecules are represented as red spheres. Hydrogen bonds are depicted with grey dotted lines and the corresponding distances are indicated.

5. Both NADH and INH-NADH are present in the active site of InhA after a 1 hour soaking of InhA crystals with INH-NADH adduct.

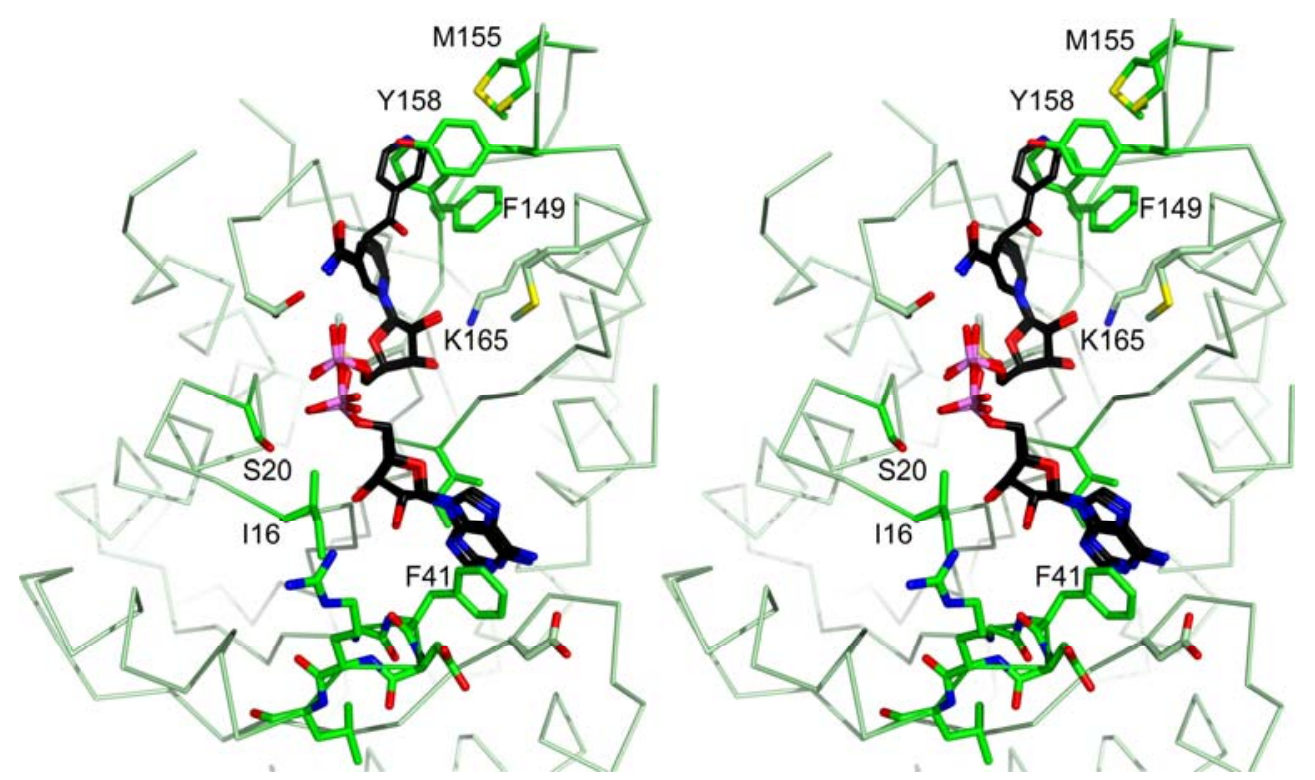

Figure S5: Stereoview of the crystal structure of InhA after 1h soaking with INH-NADH. Both $\mathrm{NADH}$ and INH-NADH are present in the active site. Ligand carbon atoms are represented in black. Side chains are represented for some residues close to the ligand. Residues affected by ligand binding are represented in light green, those unaffected are in pale green. 